\title{
A comparative study of the metal binding behavior of alanine based bis-thiourea isomers
}

\author{
Imran Fakhar, Bohari M. Yamin and Siti Aishah Hasbullah*
}

\begin{abstract}
Two new symmetrical bis-thiourea, 2,2'-[\{(terephthaloylbis(azanediyl)bis(carbonothioyl) bis(azanediyl)\}dipropanoic acid] (1A) and 3,3'-[(terephthaloylbis(azanediyl)bis (carbonothioyl)bis(azanediyl)\} dipropanoic acid] (1B) were synthesized by the reaction of terephthaloyl chloride with $a$ - and $\beta$-alanine in good yields. Their binding properties were investigated with various metal cations using UV-Vis titration experiments. Both isomers exhibited effective binding with $\mathrm{Ag}^{+}, \mathrm{Cu}^{2+}, \mathrm{Hg}^{2+}, \mathrm{Pb}^{2+}, \mathrm{Fe}^{2+}$ and $\mathrm{Fe}^{3+}$ cations. However, in the presence of other cations, such as $\mathrm{Na}^{+}, \mathrm{Ni}^{2+}, \mathrm{Co}^{2+}$, $\mathrm{Cd}^{2+}, \mathrm{Zn}^{2+}, \mathrm{Mn}^{2+}, \mathrm{Mg}^{2+}, \mathrm{Ca}^{2+}, \mathrm{Sn}^{2+}, \mathrm{Al}^{3+}$, and anions tetrabutylammonium $\mathrm{Cl}^{-}$and $\mathrm{H}_{2} \mathrm{PO}_{4}{ }^{-}$, no interaction occurred. Both isomers displayed similar trends towards binding with metal cations.
\end{abstract}

Keywords: Bis-thiourea isomers, Binding study, $a$ - and $\beta$-alanine, Metal cations

\section{Introduction}

Thiourea is an analogue of urea and was first synthesized by Nencki [1]. Since then, thiourea compounds have extensively been used as the building blocks of heterocyclic analogues [2]. Amongst this class of compounds, benzoyl derivatives of thiourea have gained a great deal of importance in the present day. Thiourea linkages have contributed greatly to the observed enhancement in various activities [3], including antiviral [4], antibacterial [5, 6], antifungal [7], antitubercular [8,9], herbicidal [10], insecticidal [11], pharmacological properties [12], as chelating agents $[13,14]$ and as anticancer compounds [15]. In addition, benzoyl thiourea derivatives have often been used in analytical and biological applications [16, 17].

Amino acids and their derivatives are significant constituents of chemical entities found within many natural frameworks. The synthesis of biologically active amino acid-coupled derivatives has recently become of major interest [18-22].

\footnotetext{
*Correspondence: aishah80@ukm.edu.my

School of Chemical Sciences and Food Technology, Faculty of Science and Technology, Universiti Kebangsaan Malaysia, 43600 UKM Bangi, Selangor, Malaysia
}

Thiourea and their amino acid derivatives coordinate to several transition metal ions to form stable complexes. Early useful suggestions of metal ions binding was provided by the old discipline of metal coordination chemistry by Werner [23]. Thioureas, along with its derivatives, are versatile ligands, able to coordinate to metal centers as neutral ligands, monoanions, or dianions [24, 25]. According to Pearson's hard and soft acid-base concept thiourea, being a soft base, shows an affinity to bind with soft acids like mercury, copper, silver, cadmium ions. Conversely, amino acids, having carboxylic acid functionality, prefer interactions with hard acids like iron, lead, aluminum ions [26]. The thiourea-based derivatives have the ability to coordinate with several metal ions but have not been much explored as receptors for the detection of transition metal ions, this despite both urea and thiourea derivatives being frequently used as anion binding receptors owing to their ability to act as hydrogen-bond donors [27, 28]. However, recently some thiourea-based derivatives and thiourea-based nanoparticles have been used to detect metal ions [29, 30]. In view of these observations, the synthesis of two bis-thiourea isomers having alanine linkers were planned followed by a comparative study of their binding interactions against sixteen metal cations (four soft, six mild and six hard ions) and two 
tetrabutyl ammonium anions. Both isomers were characterized by IR spectroscopy, ${ }^{1} \mathrm{H}$ and ${ }^{13} \mathrm{C}$ NMR spectroscopy, ESI-MS, and elemental analysis. Isomer 1B was further confirmed by X-ray crystallography. Binding studies of both isomers were studied by conducting titration experiments using UV-Vis spectroscopy.

\section{Experimental}

\section{Materials and measurements}

All the chemicals were obtained from ACROS Organics (Geel, Belgium) and Sigma-Aldrich (Saint Louis, MO, USA), and were utilized without further purification. All solvents were distilled from $\mathrm{CaH}_{2}$ before use. Open tube capillary method was used to determine the melting points utilizing an Electrothermal 9100 (Electrothermal, Southend, England) and were uncorrected. The micro elemental investigation for CHNS were performed using a Carlo Erba 1108 Elemental Analyzer (Milan, Italy). The IR spectra of the isomers were obtained by $\mathrm{KBr}$ disc method and were recorded on a Perkin Elmer Spectrum GX spectrophotometer (Perkin Elmer, Waltham, MA, USA) in the range of $400-4000 \mathrm{~cm}^{-1}$ with resolution $4 \mathrm{~cm}^{-1}$. UV-Vis estimations were performed on double beam Varian UV 3.0 (Cary 100, Varian Australia Pty. Ltd.) spectrophotometer with a quartz cell (1 cm path length) in the scope of 200-800 $\mathrm{nm}$ with the highest resolution of $1 \mathrm{~nm}$. Nuclear Magnetic Resonance experiments $\left({ }^{1} \mathrm{H}\right.$ and ${ }^{13} \mathrm{C}$ NMR spectra) were done on a Bruker $400 \mathrm{MHz}$ instrument using DMSO- $\mathrm{d}_{6}$ as solvent. ESI-MS spectra were recorded on a Micro Tof Q (Bruker, AXS Incorporation, and Madison, WI, USA). Single crystal X-ray experiments were performed on a Bruker D-QUEST diffractometer (Bruker, AXS Inc., Madison, WI, USA) using graphite-monochromated Mo-K $\alpha$ radiation $(\lambda=0.71073 \AA)$. Intensity data were measured at room temperature by the $\omega$-scan. Accurate cell parameters and orientation matrix were determined by the full-matrix least-squares fit of 25 reflections. Intensity data were collected for Lorentz and polarization effects. Empirical absorption correction was carried out using multi-scan. The structure was solved by direct methods and leastsquares refinement of the structure was performed by the SHELXL-2007 program [31]. All the non-hydrogen atoms were refined anisotropically. The hydrogen atoms were set in the calculated positions aside from the terminal $\mathrm{N}$-atoms of thiourea moiety located from Fourier maps and refined isotropically [32].

General procedure for the synthesis of isomers (1A and 1B) Benzene-1,4-dicarbonyl chloride (terephthaloyl chloride) $(0.609 \mathrm{~g}, 0.003 \mathrm{~mol})$, was dissolved in dry acetone $(20 \mathrm{ml})$. A solution of ammonium thiocyanate $(0.456 \mathrm{~g}$,
$0.006 \mathrm{~mol})$, antecedently dried $\left(80{ }^{\circ} \mathrm{C}, 2 \mathrm{~h}\right)$ in dry acetone $(15 \mathrm{ml})$ was prepared. Ammonium thiocyanate was added slowly to the stirring solution of benzene-1, 4-dicarbonyl chloride, and the reaction mixture was stirred at room temperature for $1 \mathrm{~h}$. The white precipitate of ammonium chloride were filtered off. $\alpha$ - or $\beta$-alanine $(0.534 \mathrm{~g}, 0.006 \mathrm{~mol})$ in dry acetone $(15 \mathrm{ml})$ was added to the filtrate containing benzene-1,4-dicarbonyl isothiocyanate intermediate. The reaction mixture was then refluxed for 24-30 h. The solution was allowed to cool to $\mathrm{RT}$ and an excess of crushed ice added to the flask, bisthiourea analogues $1 \mathrm{~A}$ and $1 \mathrm{~B}$ were collected as precipitates which were then washed several times with water and dried in a desiccator (using calcium sulfate as a drying agent). Both analogues were recrystallized from ethanol/DMSO to afford 1A and 1B in good yield (89.1 and $91.8 \%$, respectively, Scheme 1).

\section{Results and discussion Characterization}

$2,2^{\prime}$ - [\{(terephthaloylbis(azanediyl)bis(carbonothioyl) bis(azanediyl)\} dipropanoic acid] (1A) Using the general method outlined above, compound 1A was isolated as a yellowish solid $(0.760 \mathrm{~g}, 89.1 \%)$, mp: $214-215{ }^{\circ} \mathrm{C}$, [Found: C, 44.99; H, 4.19; N, 13.11; S, 15.01; O, 22.7\%; $\mathrm{M}^{+}$, 449.07. $\mathrm{C}_{16} \mathrm{H}_{18} \mathrm{~N}_{4} \mathrm{O}_{6} \mathrm{~S}_{2}$ requires $\mathrm{C}$, 45.06; $\mathrm{H}, 4.25 ; \mathrm{N}$, 13.14; S, 15.04; O, 22.51\%]; $v_{\max }\left(\mathrm{KBr} / \mathrm{cm}^{-1}\right) 3358(\mathrm{~N}-\mathrm{H})$, $3180\left(\mathrm{C}-\mathrm{H}_{\text {arom }}\right), 2929\left(\mathrm{C}-\mathrm{H}_{\text {aliph }}\right), 1728(\mathrm{C}=\mathrm{O}), 1676$ $(\mathrm{COOH}), 1545(\mathrm{C}-\mathrm{N}), 1521(\mathrm{Ar}-\mathrm{C}), 1012(\mathrm{C}=\mathrm{S}) ; \delta \mathrm{H}$ $\left(400 \mathrm{MHz}\right.$, DMSO-d $\mathrm{d}_{6}, 1.50\left(6 \mathrm{H}, \mathrm{d}, \mathrm{J}=7.2 \mathrm{~Hz}, 2 \times \mathrm{CH}_{3}\right)$, $4.83(2 \mathrm{H}$, quint, $\mathrm{J}=7.2 \mathrm{~Hz}, 2 \times \mathrm{CH}), 8.00(4 \mathrm{H}, \mathrm{s}, \mathrm{Ar}-\mathrm{H})$, $11.24(2 \mathrm{H}, \mathrm{d}, \mathrm{J}=6.8 \mathrm{~Hz}, 2 \times \mathrm{NH}), 11.74(2 \mathrm{H}, \mathrm{s}, 2 \times \mathrm{NH})$. $\delta \mathrm{C}\left(100 \mathrm{MHz}, \mathrm{DMSO}-\mathrm{d}_{6}\right) 17.5\left(\mathrm{CH}_{3}\right), 53.5(\mathrm{CH}), 129.0$ $\left(\mathrm{CH}_{\text {arom }}\right), 136.3\left(\mathrm{C}_{\text {arom }}\right), 168.2(\mathrm{C}=\mathrm{O}), 173.3(\mathrm{COOH})$, $180.1(\mathrm{C}=\mathrm{S}) ; \mathrm{MS}(\mathrm{EI}):(m / z)=449.07[\mathrm{M}+\mathrm{Na}]^{+}$.

\section{$3,3^{\prime}-[\{($ terephthaloylbis(azanediyl)bis(carbonothioyl)} bis(azanediyl)\} dipropanoic acid] (1B) Using the general method outlined above, compound 1B was isolated as a white solid $(0.784 \mathrm{~g}, 91.8 \%)$ as a white solid, mp: 203-204 ${ }^{\circ} \mathrm{C}$, [Found: C, 45.09; H, 4.31; N, 13.01; S, 15.03; $\mathrm{O}, 22.56 \% ; \mathrm{M}^{+}$, 449.47. $\mathrm{C}_{16} \mathrm{H}_{18} \mathrm{~N}_{4} \mathrm{O}_{6} \mathrm{~S}_{2}$ requires $\mathrm{C}$, 45.06; $\mathrm{H}, 4.25$; N, 13.14; S, 15.04; O, 22.51\%]; $v_{\max }\left(\mathrm{KBr} / \mathrm{cm}^{-1}\right)$ $3330(\mathrm{~N}-\mathrm{H}), 3245\left(\mathrm{C}-\mathrm{H}_{\text {arom }}\right), 2950\left(\mathrm{C}-\mathrm{H}_{\text {aliph }}\right), 1711$ $(\mathrm{C}=\mathrm{O}), 1670(\mathrm{COOH}), 1554(\mathrm{C}-\mathrm{N}), 1527(\mathrm{Ar}-\mathrm{C}), 1025$ $(\mathrm{C}=\mathrm{S}) ; \delta \mathrm{H}\left(400 \mathrm{MHz}, \mathrm{DMSO}-\mathrm{d}_{6}, 2.65(4 \mathrm{H}, \mathrm{t}, \mathrm{J}=6.0 \mathrm{~Hz}\right.$, $\left.2 \times \mathrm{CH}_{2}\right), 3.82\left(4 \mathrm{H}, \mathrm{d}, \mathrm{J}=6.0 \mathrm{~Hz}, 2 \times \mathrm{CH}_{2}\right), 7.95(4 \mathrm{H}$, s, $\mathrm{Ar}-\mathrm{H}), 10.99(2 \mathrm{H}, \mathrm{t}, \mathrm{J}=5.6 \mathrm{~Hz}, 2 \times \mathrm{NH}), 11.49(2 \mathrm{H}$, s, $2 \times \mathrm{NH}) . \delta \mathrm{C}\left(100 \mathrm{MHz}, \mathrm{DMSO}-\mathrm{d}_{6}\right) 32.6\left(\mathrm{CH}_{2}\right), 41.0$ $\left(\mathrm{CH}_{2}\right), 127.8\left(\mathrm{CH}_{\text {arom }}\right), 129.0\left(\mathrm{C}_{\text {arom }}\right), 168.0(\mathrm{C}=\mathrm{O})$, 173.4 $(\mathrm{C}=\mathrm{OOH}), 180.5(\mathrm{C}=\mathrm{S})$; $\mathrm{MS}(\mathrm{EI}):(\mathrm{m} / z)=449.47$ $[\mathrm{M}+\mathrm{Na}]^{+}$. 


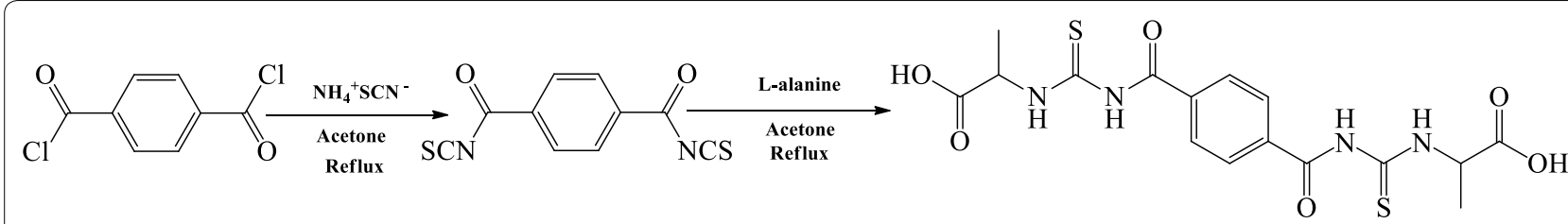

Terephthaloyl chloride

Terephthaloyl isothiocyanate

isomer $1 \mathrm{~A}$

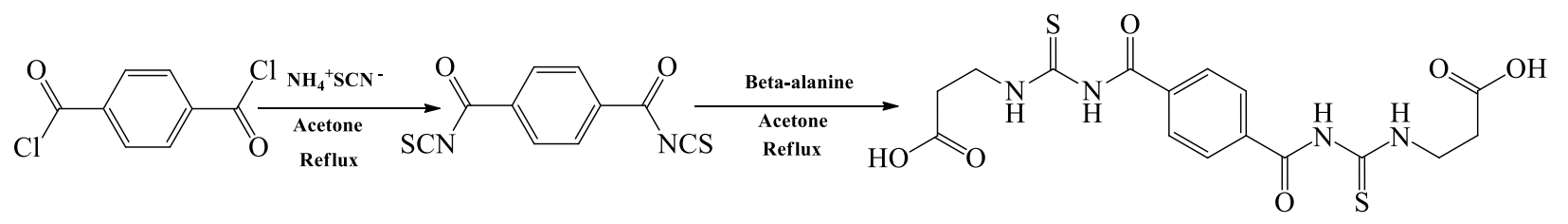

Terephthaloyl chloride

Terephthaloyl isothiocyanate

Isomer 1B

Scheme 1 Synthesis of bis-thiourea alanine based isomers $1 \mathrm{~A}$ and 1B

\section{IR spectroscopy}

IR spectra of both isomers were in accordance with the vibrational frequencies of the functional groups as found in the literature $[3,46]$. The $\mathrm{N}-\mathrm{H}$ stretching vibrations were observed in the range $3330-3358 \mathrm{~cm}^{-1}$. The $\mathrm{O}-\mathrm{H}$ stretching frequencies of the carboxylic groups were overlapped by $\mathrm{N}-\mathrm{H}$ stretching peak and hence could not be observed. The $\mathrm{C}-\mathrm{H}$ stretching vibrations for the $\mathrm{sp}^{2}$ carbon of the aromatic ring of both isomers were observed in the range $3180-3245 \mathrm{~cm}^{-1}$ [33] whereas, the $\mathrm{C}-\mathrm{H}$ stretching vibrations for the $\mathrm{sp}^{3}$ mode of the alkyl chain were observed in the range $2930-2950 \mathrm{~cm}^{-1}$ [34]. The frequency for the $\mathrm{C}=\mathrm{O}$ and $\mathrm{C}=\mathrm{O}_{\text {carboxylic }}$ stretches were observed at 1728 , 1676,1711 , and $1670 \mathrm{~cm}^{-1}$ for the isomers $1 \mathrm{~A}$ and $1 \mathrm{~B}$, respectively [35]. The $v(\mathrm{C}-\mathrm{N})$ and $v\left(\mathrm{C}=\mathrm{C}_{\text {aromatic }}\right)$ vibrational frequencies were observed at 1545, 1521 and 1554, $1527 \mathrm{~cm}^{-1}$ for isomers $1 \mathrm{~A}$ and $1 \mathrm{~B}$, respectively. All of the values mentioned were found in accordance with those reported [3]. The $v(\mathrm{C}=\mathrm{S})$ vibrational frequencies for both isomers were observed at 1012 and $1025 \mathrm{~cm}^{-1}$. The lowering in the vibrational frequencies of $(C=S)$ bonds were due to mesomeric electron releasing effect of the nitrogen bonded to the thiocarbonyl group $(\mathrm{N}-\mathrm{C}=\mathrm{S})$. This lowering of $\mathrm{C}=\mathrm{S}$ stretching frequencies is due to an acquiring of a partial polar character [36].

\section{${ }^{1} \mathrm{H}$ NMR and ${ }^{13} \mathrm{C}$ NMR spectroscopy}

Bis-thiourea isomers were further characterized and confirmed by ${ }^{1} \mathrm{H}$, and ${ }^{13} \mathrm{C}$ NMR. The proton chemical shifts of the amide functionality appeared as a singlet at $\delta 11.74$ and $11.49 \mathrm{ppm}$ for isomers $1 \mathrm{~A}$ and $1 \mathrm{~B}$, respectively. The thioamide protons were observed as doublets at $\delta 11.24$,
$10.99 \mathrm{ppm}$ for the isomers $1 \mathrm{~A}$ and $1 \mathrm{~B}$, respectively. The downfield signals of both amide and thioamide protons are due to the formation of $\mathrm{H}$-bonding between the amino proton and the oxygen/sulfur atoms of carbonyl/ thiocarbonyl group, as well as the anisotropic effect [37]. All the aromatic protons for both isomers were identical and found as singlets at $\delta 8.0$ and $7.95 \mathrm{ppm}$ for $1 \mathrm{~A}$ and $1 \mathrm{~B}$, respectively. The chemical shift for the proton on the chiral carbon of isomer $1 \mathrm{~A}$ was observed at $\delta 4.83 \mathrm{ppm}$. The signal was observed downfield due to the deshielding effect of the nearby electron withdrawing thioamide group as well as the anisotropic effect of the carboxylic carbonyl group. Isomer 1B contains no source of chirality and so two methylene groups are present. The methylene group proximal to the carboxylic acid were observed downfield at $\delta 3.82 \mathrm{ppm}$ as a doublet due to the anisotropic effect of the carbonyl group. Protons of the second methylene group were observed as a triplet at $\delta 2.65 \mathrm{ppm}$ slightly downfield due to deshielding from the electron withdrawing thioamide group. The methyl protons for isomer $1 \mathrm{~A}$ were observed as a doublet at $\delta 1.53 \mathrm{ppm}$.

The ${ }^{13} \mathrm{C}$ NMR spectra for both isomers $1 \mathrm{~A}$ and $1 \mathrm{~B}$ were in accordance with those that have been reported previously [38]. The carbon chemical shifts of $\mathrm{C}=\mathrm{S}$, $\mathrm{C}=\mathrm{C}_{\text {arboxylic }}$ and $\mathrm{C}=\mathrm{O}$ were found at $\delta 180.1,173.3$ and $168.2 \mathrm{ppm}$ for isomer $1 \mathrm{~A}$ and at $\delta 180.5,173.4$ and 168.0 for isomer $1 \mathrm{~B}$, respectively. The aromatic carbons were observed at $\delta 129.0$ and $136.3 \mathrm{ppm}$ for isomer $1 \mathrm{~A}$ and at $\delta 127.8$ and $129.0 \mathrm{ppm}$ for isomer $1 \mathrm{~B}$, respectively. The signal for the chiral carbon of isomer $1 \mathrm{~A}$ was observed at $\delta 53.5 \mathrm{ppm}$ and that of the carbon bearing the methyl group at $\delta 17.5 \mathrm{ppm}$. Whereas the chemical shifts of two 
methylene groups of isomer 1B were observed at $\delta 3.82$ and $2.65 \mathrm{ppm}$, respectively.

\section{Elemental analysis and ESI-Mass spectroscopy}

The CHNS analysis for both isomers were found to be in close accordance with the theoretical values.

The ESI-MS spectra, for both isomers $1 \mathrm{~A}$ and $1 \mathrm{~B}$, showed sodium molecular ion peaks at $m / z 449$, which is in accordance with the expected molecular ion peak values.

\section{X-ray crystallography of isomer 1B}

The isomer $1 \mathrm{~B}$ crystallized in monoclinic system with space group $\mathrm{C} 2 / \mathrm{c}, \mathrm{a}=26.9433(13), \mathrm{b}=4.7668(2), \mathrm{c}=15.1750(7)$, $\alpha=90, \beta=100.926(2), \gamma=90, Z=4$ and $V=1913.65(15)$. Crystallographic data for the structure determination has been deposited with the Cambridge Crystallographic Data number CCDC 1518921. The given crystal state and refinement parameters are given in Table 1.

The molecule $1 \mathrm{~B}$ adopts a cis-trans configuration with respect to the position of the propionic acid relative to the $S_{1}$ atom across the $C(4)-N(1)$ bonds. Figure 1 shows the conformational structure of the molecule with atoms numbered.

The thiourea fragment, $\mathrm{S}(1) / \mathrm{N}(1) / \mathrm{N}(2) / \mathrm{O}(3) / \mathrm{C}(5)$ and benzene ring are planar with maximum deviation of 0.073(2) $\AA$ for the $\mathrm{N}(1)$ atom from the least-squares plane of the thiourea fragment. The thiourea moiety along with benzene ring makes an angle of $90.0(3)^{\circ}$ with the propionic acid fragment (Table 2). The bond lengths and angles in isomer $1 \mathrm{~B}$ is within normal ranges $[39,40]$.

In the molecule there are three intramolecular H-bonds, $\quad \mathrm{N}(1) \ldots \mathrm{H}(1) \ldots \mathrm{O}(3), \quad \mathrm{C}(3) \ldots \mathrm{H}(3 \mathrm{~B}) \ldots \mathrm{S}(1)$ and
Table 1 Crystal data and structure refinement for isomer 1B

Identification code
Empirical formula
Formula weight
Temperature
Wavelength
Crystal system
Space group
Unit cell dimensions

Volume

Z

Density (calculated)

Absorption coefficient

$\mathrm{F}(000)$

Crystal size

Theta range for data collection Index ranges

Reflections collected

Independent reflections

Completeness to theta $=28.31^{\circ}$

Absorption correction

Max. and min. transmission

Refinement method

Data/restraints/parameters

Goodness-of-fit on $F^{2}$

Final $R$ indices [I >2 sigma(I)]

$R$ indices (all data)

Largest diff. peak and hole

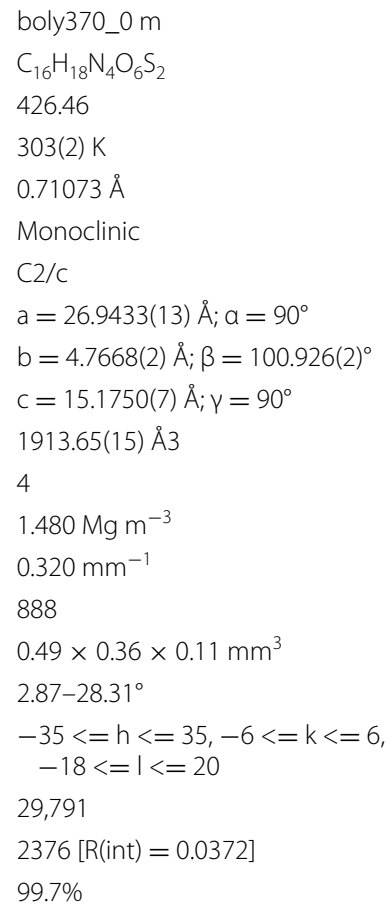

Semi-empirical from equivalents 0.9656 and 0.8588

Full-matrix least-squares on $\mathrm{F}^{2}$

2376/0/128

1.064

$R 1=0.0538, w R 2=0.1507$

$R 1=0.0673, w R 2=0.1618$

0.335 and -0.357 e $\AA^{-3}$

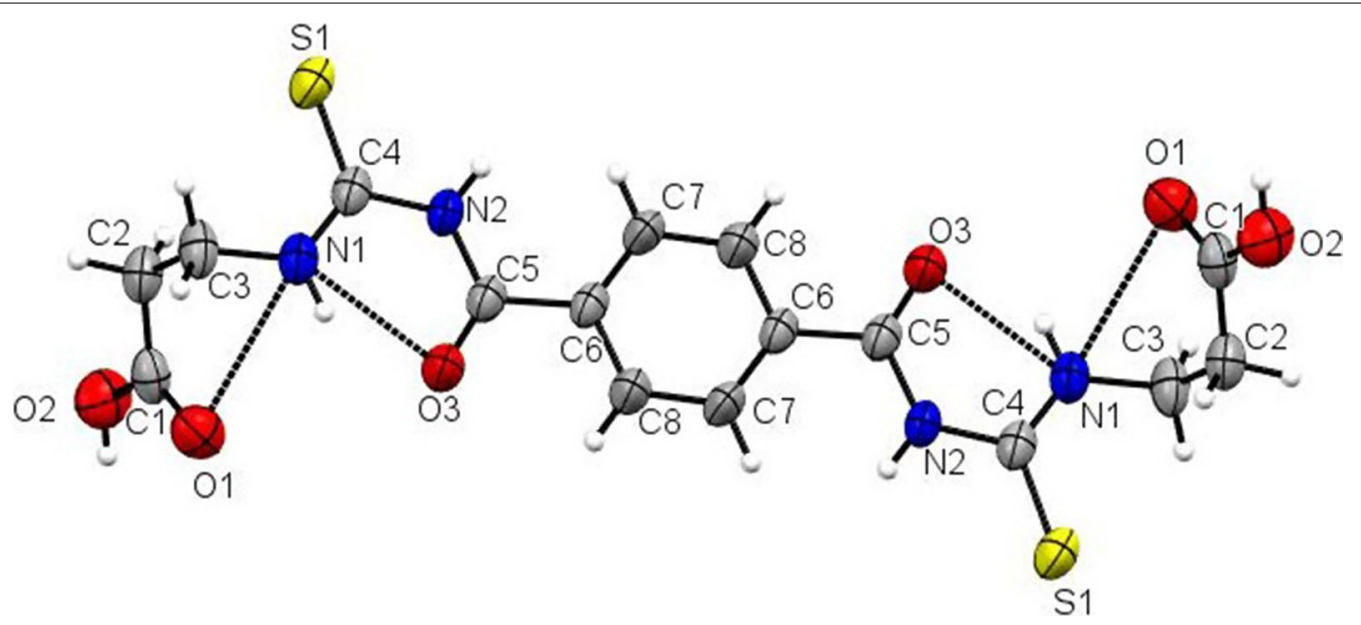

Fig. 1 ORTEP diagram of the 3, 3'-[\{(terephthaloylbis(azanediyl)bis(carbonothioyl)bis (azanediyl)\}dipropanoicacid]. 1B was drawn at 50\% probability displacement ellipsoids. The dashed line indicates the intramolecular hydrogen bond 
Table 2 Selected bond lengths ( $\AA$ ) and bond angles $\left({ }^{\circ}\right)$ for isomer 1B

\begin{tabular}{|c|c|c|c|}
\hline Bond & Length $(\AA ̊)$ & Bond & Angles $\left({ }^{\circ}\right)$ \\
\hline$S(1)-C(4)$ & $1.672(2)$ & $C(4)-N(1)-C(3)$ & $123.7(2)$ \\
\hline$O(1)-C(1)$ & $1.212(3)$ & $C(5)-N(2)-C(4)$ & $126.52(18)$ \\
\hline $\mathrm{O}(2)-\mathrm{C}(1)$ & 1.313(3) & $\mathrm{O}(1)-\mathrm{C}(1)-\mathrm{O}(2)$ & 122.1(2) \\
\hline$O(3)-C(5)$ & $1.214(3)$ & $\mathrm{O}(1)-\mathrm{C}(1)-\mathrm{C}(2)$ & $124.6(2)$ \\
\hline$N(1)-C(4)$ & $1.316(3)$ & $\mathrm{O}(2)-\mathrm{C}(1)-\mathrm{C}(2)$ & 113.26(19) \\
\hline$N(1)-C(3)$ & $1.464(3)$ & $C(1)-C(2)-C(3)$ & $112.6(2)$ \\
\hline$N(2)-C(5)$ & $1.377(3)$ & $N(1)-C(3)-C(2)$ & $111.31(19)$ \\
\hline$N(2)-C(4)$ & $1.399(2)$ & $N(1)-C(4)-N(2)$ & 116.77(18) \\
\hline$C(1)-C(2)$ & $1.494(4)$ & $N(1)-C(4)-S(1)$ & $122.86(16)$ \\
\hline$C(2)-C(3)$ & $1.514(3)$ & $N(2)-C(4)-S(1)$ & $120.35(16)$ \\
\hline$C(5)-C(6)$ & $1.500(3)$ & $\mathrm{O}(3)-\mathrm{C}(5)-\mathrm{N}(2)$ & $122.32(18)$ \\
\hline$C(6)-C(7)$ & $1.371(3)$ & $\mathrm{O}(3)-\mathrm{C}(5)-\mathrm{C}(6)$ & 120.38(19) \\
\hline$C(6)-C(8)$ & $1.377(3)$ & $N(2)-C(5)-C(6)$ & 117.30(19) \\
\hline$C(7)-C(8) \# 1$ & $1.382(3)$ & $C(7)-C(6)-C(8)$ & 118.52(19) \\
\hline \multirow[t]{2}{*}{$C(8)-C(7) \# 1$} & $1.382(3)$ & $C(7)-C(6)-C(5)$ & $124.88(18)$ \\
\hline & & $C(8)-C(6)-C(5)$ & 116.59(19) \\
\hline
\end{tabular}

Symmetry transformations used to generate equivalent atoms: $\# 1-x,-y,-z$
Table 3 Hydrogen bonds for isomer 1B $\left[(\AA \AA)\right.$ and $\left.\left(^{\circ}\right)\right]$

\begin{tabular}{|c|c|c|c|c|}
\hline D-H...A & $d(D-H)$ & $d(H \ldots A)$ & $d(D \ldots A)$ & $<(\mathrm{DHA})$ \\
\hline $\mathrm{N}(2)-\mathrm{H}(2 \mathrm{C}) \ldots \mathrm{O}(1)$ & 0.86 & 2.28 & $3.126(2)$ & 168 \\
\hline $\mathrm{N}(1)-\mathrm{H}(1) \ldots O(3)$ & 0.86 & 1.92 & $2.603(2)$ & 134.9 \\
\hline $\mathrm{O}(2)-\mathrm{H}(2) \ldots \mathrm{S}(1)$ & 0.82 & 2.26 & $3.072(2)$ & 174 \\
\hline$C(3)-H(3 B) \ldots S(1)$ & 0.97 & 2.64 & $3.042(3)$ & 105 \\
\hline $\mathrm{C}(7)-\mathrm{H}(7) \ldots \mathrm{O}(1)$ & 0.93 & 2.20 & $3.123(3)$ & 174 \\
\hline $\mathrm{C}(8)-\mathrm{H}(8) \ldots \mathrm{O}(3)$ & 0.93 & 2.41 & $2.737(3)$ & 100 \\
\hline
\end{tabular}

$\mathrm{C}(8) \ldots \mathrm{H}(8) \ldots \mathrm{O}(3)$ (Table 3 ). In the crystal structure, the molecules are linked by $\mathrm{O}(2) \ldots \mathrm{H}(2) \ldots \mathrm{S}(1), \mathrm{N}(1) \ldots$ $\mathrm{H}(2 \mathrm{C}) \ldots \mathrm{O}(1)$ and $\mathrm{C}(7) \ldots \mathrm{H}(7) \ldots \mathrm{O}(1)$ intermolecular H-bonds forming a 3-D network (Fig. 2).

\section{Binding studies}

UV-Vis spectra measurements

Firstly, stock solutions for both isomers (1A and $1 \mathrm{~B})$ were prepared in DMSO $\left(1 \times 10^{-3} \mathrm{M}\right)$ before making

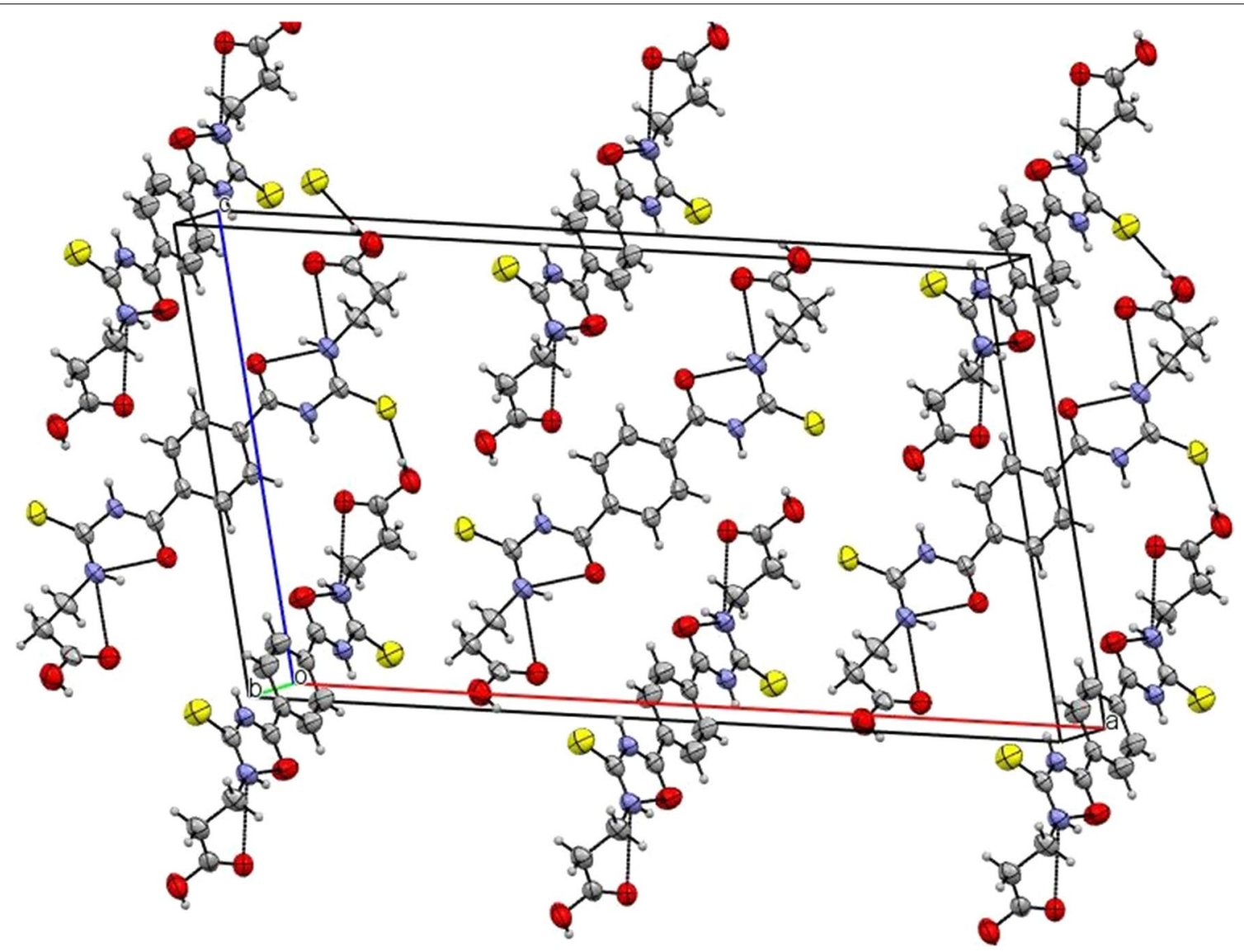

Fig. 2 Molecular packing of $1 \mathrm{~B}$ viewed down the $\mathrm{b}$ axis. Dashed lines denote $\mathrm{C}-\mathrm{H} \ldots . \mathrm{O}, \mathrm{O}-\mathrm{H} \ldots \mathrm{S}$ and $\mathrm{N}-\mathrm{H} \ldots . \mathrm{O}$ hydrogen bonds 
stock solutions for both metal cations and tetrabutylammonium anions, also in DMSO $\left(1 \times 10^{-3} \mathrm{M}\right)$. By adding different volumes $(0-600 \mu \mathrm{l})$ of metal ions and terabutylammonium anions to a series volumetric flasks, together with an equal volume $(100 \mu \mathrm{l})$ of the isomers $1 \mathrm{~A}$ and $1 \mathrm{~B}$, the work solutions were prepared. Each of the work solutions were then diluted by adding DMSO and shaken for several minutes. Readings were recorded on UV-Vis spectrophotometer using quartz cuvettes ( $1 \mathrm{~cm}$ path length) in the range of $200-800 \mathrm{~nm}$ with the utmost resolution of $1 \mathrm{~nm}$. The correlation coefficient was computed using Pearson product-moment correlation strategy. By plotting a fit line curve using Sigma Plot 12.0 (Systat Software Inc.), dissociation constant $\left(K_{d}\right)$ values were intended using a nonlinear regression equation. Detection limit was figured by $3 \sigma / S$, where ' $\sigma$ ' is the std. deviation and ' $\mathrm{S}$ ' is the incline in the titration curve. To demonstrate the veracity of information, more than 20 arrangements of continuous data were gathered in the UV-Vis titration tests until absorbance values approached equilibrium.

\section{Theory and calculations}

The correlation coefficient was utilized to quantify a linear association between the two factors (absorbance vs concentration) amid the titration tests. The Pearson product-moment correlation strategy was utilized as part of this study to quantify the degree of linear dependence between the two variables. The formula for correlation coefficient ' $r$ ' can be accomplished by substituting assessments of the covariance and variance in the equation below [47].

$$
r=r x y=\frac{n\left(\sum x y\right)-\left(\sum x\right)\left(\sum y\right)}{\left(n \sqrt{\sum x^{2}-(x)^{2}}\right)\left(n \sqrt{\sum y^{2}-\left(\sum y\right)^{2}}\right)}
$$

where: $\mathrm{r}=$ correlation coefficient; $\mathrm{x}=$ concentration; $\mathrm{y}=$ absorbance; $\mathrm{n}=$ no. of observations.

The detection limit was calculated by utilizing the formula.

$$
D L=3 \sigma / S
$$

where: $\sigma=$ std. deviation of 5 blank values; $\mathrm{S}=$ slope of the fit-line titration curve.

\section{Clark's theory of binding}

Alfred Joseph Clark developed this concept in 1926, and mathematically stated that for a bimolecular reaction [48]:

$$
H+G \leftrightarrows H-G
$$

The equilibrium dissociation constant $\left(\mathrm{K}_{\mathrm{d}}\right)$ or an equilibrium association constant $\left(\mathrm{K}_{\mathrm{a}}\right)$, which are proportionally related, is demonstrated by the following:

$$
K_{d}=\frac{[H][G]}{[H-G]} \Longleftrightarrow K_{a}=\frac{[H-G]}{[H][G]} \Longleftrightarrow
$$

Regardless of the mechanism, every reversible reaction achieves equilibrium conveyance of reactants and products when the rates of both the forward and reverse reactions reach equivalence. The general rate can be communicated as:

$$
\frac{d[H-G]}{d t}=k_{\text {assn }}[H][G]-k_{d i s s}[H-G] .
$$

At the beginning of a reaction, the association rate $\left(k_{\text {assn }}[H][G]\right)$ would overwhelm. As more of the complex is formed, the association rate would diminish and the dissociation rate would increase. Eventually, the rates of the opposing reactions would become equivalent, and be described as:

$$
\begin{aligned}
\frac{d[H-G]}{d t} & =\frac{-d[H]}{d t}=\frac{-d[G]}{d t} \\
& =k_{\text {assn }}[H][G]-k_{\text {diss }}[H-G]=0 .
\end{aligned}
$$

Under these conditions:

$$
\frac{[H][G]}{[H-G]}=\frac{k_{\text {diss }}}{k_{\text {ass }}}=K_{d}
$$

This expression demonstrates that the equilibrium concentration of reactants and products will have a constant ratio $\left(K_{d}\right)$ that is equivalent to the proportion of the forward and reverse rate constants. $K_{d}$ is called the equilibrium dissociation constant.

In the present study the dissociation constant (also termed as binding constant $\left(\mathrm{K}_{\mathrm{d}}\right)$ was computed by the Nonlinear Regression formula utilizing Sigma plot 12.0 (Systat Software Inc.).

For the two site mode of binding (Fig. 3), the nonlinear regression equation is expressed as the following:

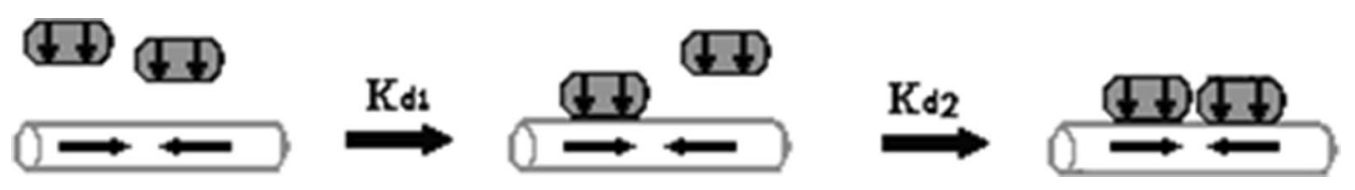

Fig. 3 Graphical representation of two-site binding 


$$
y=B_{\max 1} \cdot \frac{x}{K_{d 1}+x}+B_{\max 2} \cdot \frac{x}{K_{d 2}+x}
$$

where: $\mathrm{B}_{\max }=$ host-guest complex; $\mathrm{y}=$ absorbance; $\mathrm{x}=[\mathrm{G}] /[\mathrm{H}]$.

\section{Selectivity of bis-thiourea isomers against cations}

In the first place, the interaction properties of the isomers in DMSO were examined against sixteen metal cations, four of which are soft metal ions such as $\mathrm{Ag}^{+}$, $\mathrm{Cu}^{2+}, \mathrm{Co}^{2+}$ and $\mathrm{Hg}^{2+}$, six are mild metal ions such as $\mathrm{Fe}^{2+}, \mathrm{Ni}^{2+}, \mathrm{Pb}^{2+}, \mathrm{Mn}^{2+}$ and $\mathrm{Zn}^{2+}$ and six are hard metal ions such as $\mathrm{Na}^{+}, \mathrm{Ca}^{2+}, \mathrm{Mg}^{2+}, \mathrm{Fe}^{3+}, \mathrm{Cd}^{2+}, \mathrm{Sn}^{2+}$ and $\mathrm{Al}^{3+}$ according to the Pearson scale. The two tetrabutylammonium anions of $\mathrm{Cl}^{-}$and $\mathrm{H}_{2} \mathrm{PO}_{4}{ }^{-}$were also investigated. Both isomers (1A and $1 \mathrm{~B})$ did not show any appreciable interactions with both $\mathrm{Cl}^{-}$and $\mathrm{H}_{2} \mathrm{PO}_{4}{ }^{-}$ions. Whereas both isomers showed reasonable interactions with six metal ions, five which are soft to mild $\mathrm{Ag}^{+}, \mathrm{Cu}^{2+}, \mathrm{Hg}^{2+}$, $\left.\mathrm{Fe}^{2+}, \mathrm{Pb}^{2+}\right)$ and one which is hard $\left(\mathrm{Fe}^{3+}\right)$. The results of interactions are shown in (Figs. 4, 5) for isomer 1A and $1 \mathrm{~B}$, respectively. On the Pearson scale thioureas are considered soft bases and so would be expected to have the most intense interactions with mild to soft Pearson acidic ions.

\section{Binding behavior and binding mechanism of bis-thiourea isomers \\ Comparison of binding behavior}

To inspect the coupling behavior of isomer $1 \mathrm{~A}$ and $1 \mathrm{~B}$ against selected metal cations, titration experiments were carried out. In the control experiment (isomers without metal cations), the absorption maxima of both isomers were seen at $265 \mathrm{~nm}$, which can be allocated to an intramolecular charge transfer (ICT) absorption band as is the known case with thioureas [41]. Upon sequential addition of cations to the test solutions, just $\mathrm{Fe}^{3+}, \mathrm{Fe}^{2+}$, $\mathrm{Cu}^{2+}, \mathrm{Pb}^{2+}, \mathrm{Hg}^{2+}$, and $\mathrm{Ag}^{+}$gave exceptional enhancement of emission intensity at $265 \mathrm{~nm}$ for both isomers $1 \mathrm{~A}$ and $1 \mathrm{~B}$. The increase of emission absorbance intensity was credited to the conceivable formation of hostguest complexes at two probable sites. The first and most likely site of complexation is the carboxylate functionality of $\alpha / \beta$-alanine [42], as shown by dissociation constant $K_{\mathrm{d} 1}$ in Table 1 . The second interaction would be from the thiourea functionality via $\mathrm{C}=\mathrm{S}$ and $\mathrm{N}-\mathrm{H}[43]$ as shown

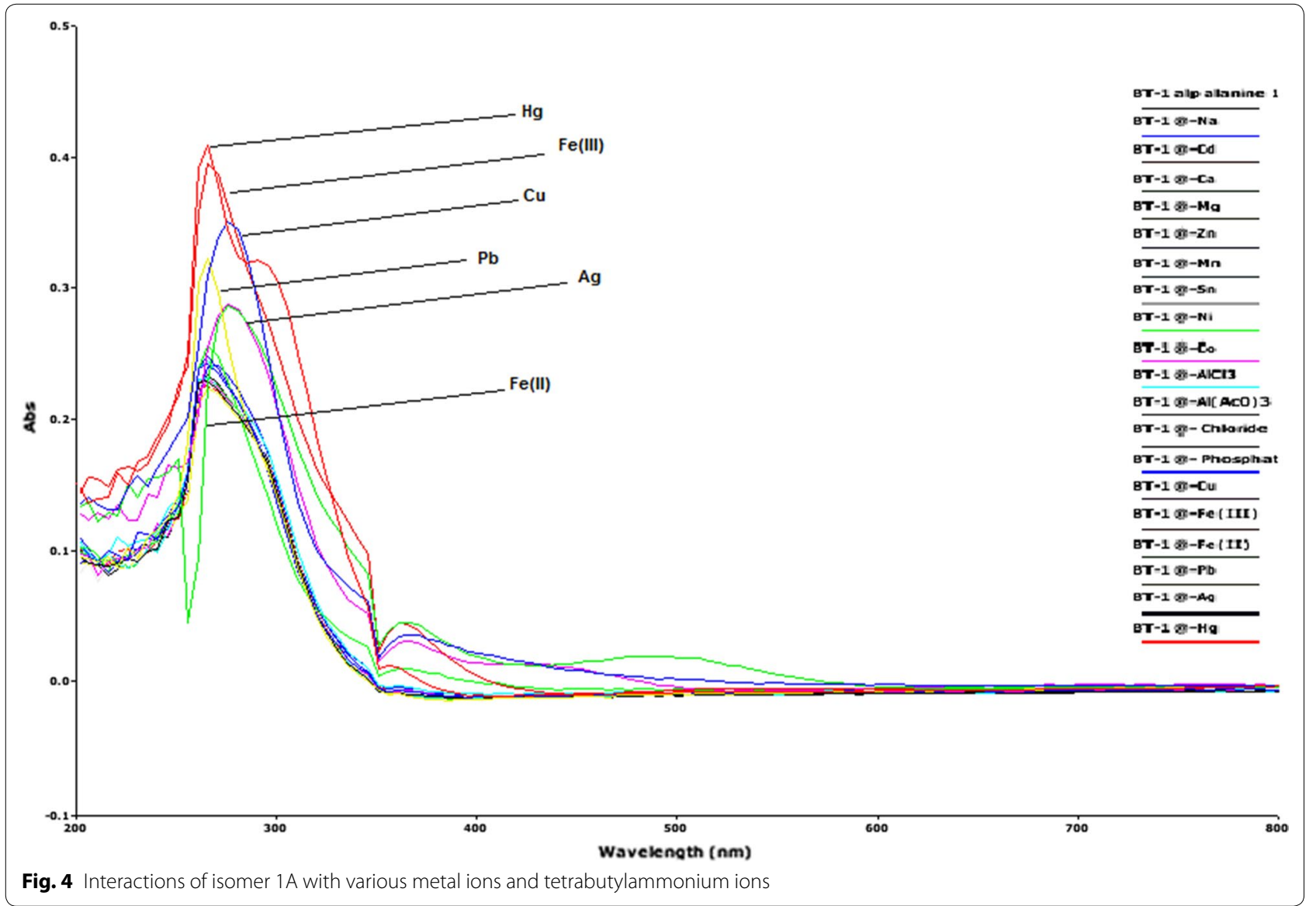




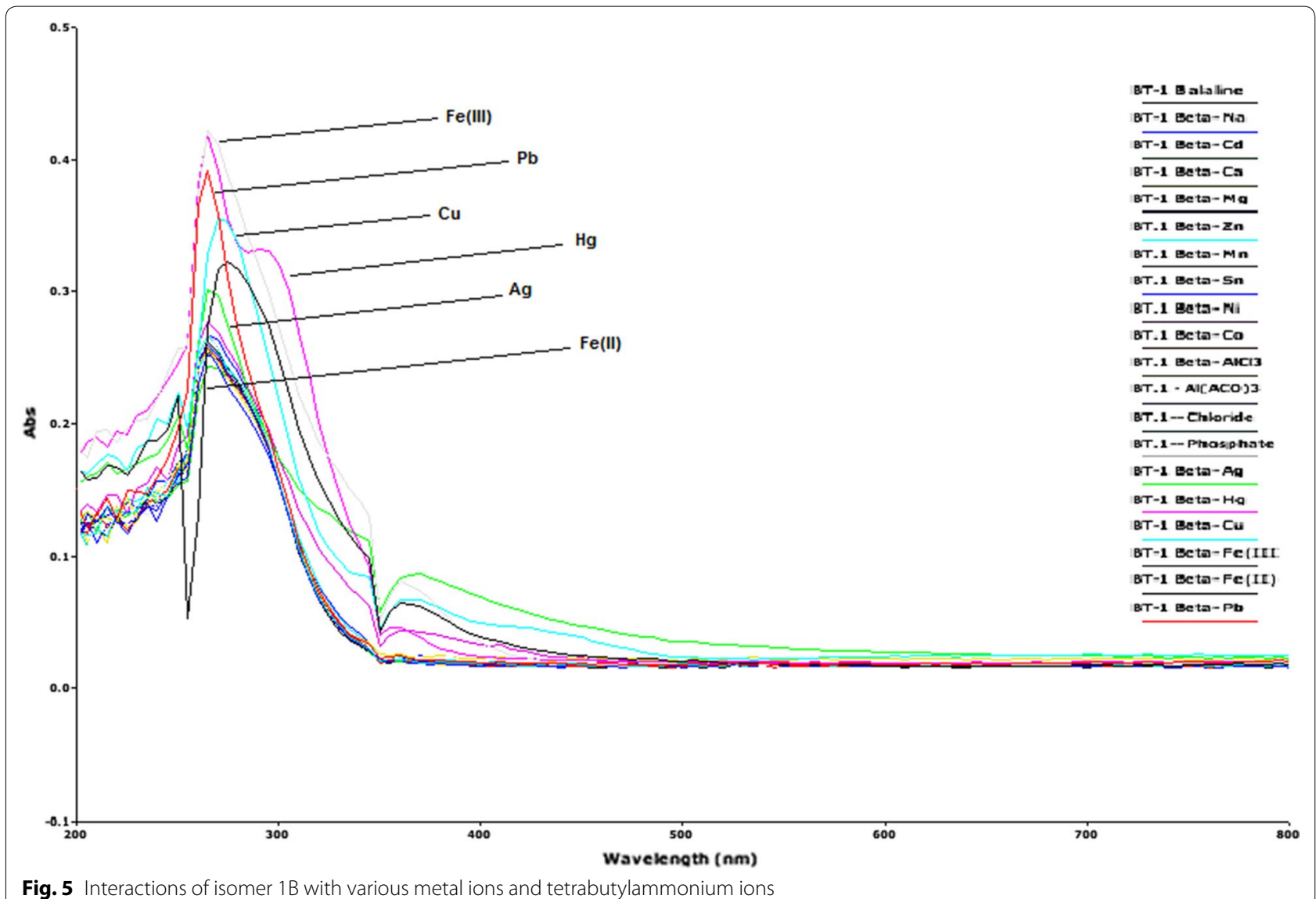

by dissociation constant $\mathrm{K}_{\mathrm{d} 2}$ (Table 1 ). By looking at the titration spectra of isomers $1 \mathrm{~A}$ and $1 \mathrm{~B}$ vs $\mathrm{Fe}^{3+}, \mathrm{Ag}^{+}$, and $\mathrm{Cu}^{2+}$ (Figs. 6, 7, 10, 11, 16, 17), another band can be seen to appear at 360-365 $\mathrm{nm}$, which progressively expanded on incremental addition of metal cations. This is due to the deprotonation of the amino proton by counter anions. Fabrizzi et al. additionally reported a similar outcome for a urea based receptor [44]. The absorbance maxima increased linearly with the concentration of all the chosen cations in a given range $(0-600 \mu \mathrm{l})$. Table 1 also shows the correlation coefficient values and detection limit values in the light of titration investigations. Titration experiment curves and binding behaviors of isomers $1 \mathrm{~A}$ and $1 \mathrm{~B}$ against metal ions are also shown (Fig. 6 through to Fig. 17).

\section{Binding mechanism}

To explore the mechanism of complexation between isomers $1 \mathrm{~A}$ and $1 \mathrm{~B}$ and the chosen metal cations, continuous variation titration investigations were carried out. In these tests, the concentration of cations was increased incrementally, whereas the concentration of isomer $1 \mathrm{~A}$ and $1 \mathrm{~B}$ were kept constant. In the light of these titration investigations, the stoichiometry of complexation between isomer $1 \mathrm{~A} / 1 \mathrm{~B}$ with metal cations were ascertained by a molar-ratio strategy [45], and the binding constant $\left(\mathrm{K}_{\mathrm{d}}\right)$ computed by nonlinear regression formula [28]. The dissociation constant $\left(K_{d}\right)$ values and stoichiometry of the complexation are shown in Table 4. The graphical counts of the stoichiometry are also shown (Inset: Figs. 6, 7, 8, 9, 10, 11, 12, 13, 14, 15, 16, 17).

\section{Conclusions}

Bis-thiourea isomers featuring amino acids $(\alpha$ and $\beta$-alanine) have been successfully characterized using spectroscopic methods, namely; IR, ${ }^{1} \mathrm{H}$ NMR, ${ }^{13} \mathrm{C}$ NMR, ESI-MS, and elemental analysis (CHNS/O). Moreover, isomer $1 \mathrm{~B}$ was further confirmed by X-ray crystallography, which revealed that the $\beta$-alanine side chain is arranged in a cis-trans configuration. The spectroscopic 
Table 4 Correlation coefficient, detection limit, stoichiometry of complexation and binding constants of both Isomers with metal ions

\begin{tabular}{|c|c|c|c|c|c|}
\hline \multirow[t]{2}{*}{ Lig-metal ion } & \multirow[t]{2}{*}{ Correlation coefficient } & \multirow[t]{2}{*}{ Detection limit } & \multirow{2}{*}{$\begin{array}{l}\text { Complexation stoichi- } \\
\text { ometry }\end{array}$} & \multicolumn{2}{|c|}{ Dissociation constant } \\
\hline & & & & Kd1 & $\mathrm{Kd} 2$ \\
\hline Isomer1A-Fe ${ }^{3+}$ & 0.982 & $1.30 \times 10^{-1} \mathrm{M}$ & $1: 4$ & $5.45 \times 10^{-17} \mathrm{M}$ & $6.760 \mathrm{M}$ \\
\hline Isomer1B-Fe $\mathrm{Fe}^{3+}$ & 0.967 & $2.40 \times 10^{-1} \mathrm{M}$ & $1: 4$ & $3.81 \times 10^{-17} \mathrm{M}$ & $4.539 \mathrm{M}$ \\
\hline Isomer1A-Fe ${ }^{2+}$ & 0.998 & $1.50 \times 10^{-1} \mathrm{M}$ & $1: 4$ & $1.42 \times 10^{-18} \mathrm{M}$ & $6.835 \mathrm{M}$ \\
\hline Isomer1B-Fe ${ }^{2+}$ & 0.936 & $3.88 \times 10^{-1} \mathrm{M}$ & $1: 4$ & $1.15 \times 10^{-17} \mathrm{M}$ & $7.380 \mathrm{M}$ \\
\hline Isomer1A-Cu²+ & 0.998 & $1.90 \times 10^{-1} \mathrm{M}$ & $1: 4$ & $6.04 \times 10^{-18} \mathrm{M}$ & $6.149 \mathrm{M}$ \\
\hline Isomer1B-Cu²+ & 0.967 & $3.16 \times 10^{-1} \mathrm{M}$ & $1: 4$ & $5.92 \times 10^{-17} \mathrm{M}$ & $9.852 \mathrm{M}$ \\
\hline Isomer1A-Pb ${ }^{2+}$ & 0.982 & $1.14 \times 10^{-1} \mathrm{M}$ & $1: 4$ & $2.84 \times 10^{-17} \mathrm{M}$ & $1.269 \mathrm{M}$ \\
\hline Isomer1B-Pb²+ & 0.977 & $1.83 \times 10^{-1} \mathrm{M}$ & $1: 4$ & $5.69 \times 10^{-17} \mathrm{M}$ & $5.310 \mathrm{M}$ \\
\hline Isomer1A-Hg ${ }^{2+}$ & 0.967 & $9.16 \times 10^{-2} \mathrm{M}$ & $1: 4$ & $9.57 \times 10^{-17} \mathrm{M}$ & $5.201 \mathrm{M}$ \\
\hline Isomer1B-Hg ${ }^{2+}$ & 0.98 & $2.10 \times 10^{-1} \mathrm{M}$ & $1: 4$ & $5.56 \times 10^{-18} \mathrm{M}$ & $7.916 \mathrm{M}$ \\
\hline Isomer1A-Ag ${ }^{+}$ & 0.997 & $2.02 \times 10^{-1} \mathrm{M}$ & $1: 4$ & $6.87 \times 10^{-18} \mathrm{M}$ & $4.557 \mathrm{M}$ \\
\hline Isomer1B-Ag ${ }^{+}$ & 0.989 & $7.23 \times 10^{-1} \mathrm{M}$ & $1: 4$ & $1.64 \times 10^{-17} \mathrm{M}$ & $1.717 \mathrm{M}$ \\
\hline
\end{tabular}

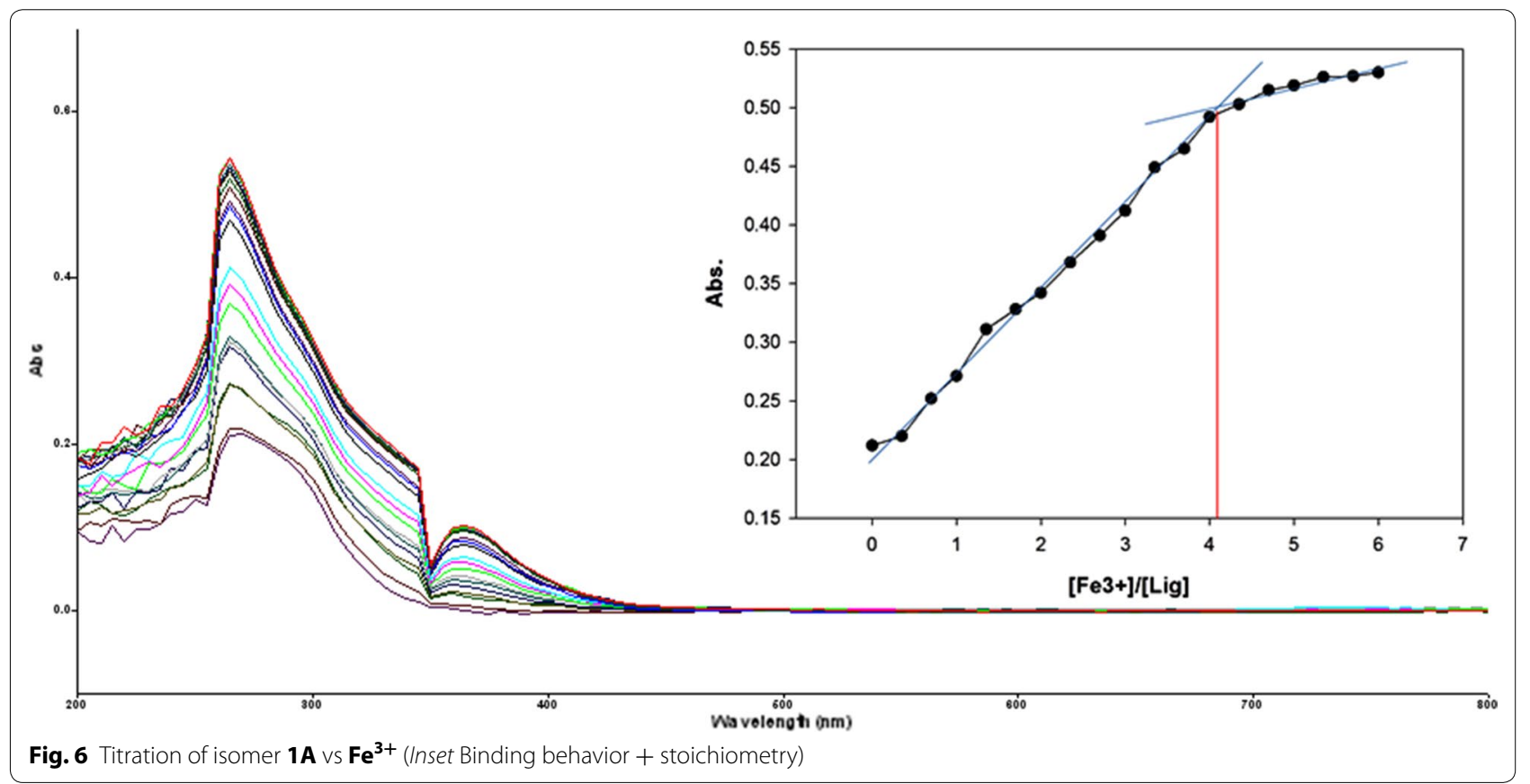

results also revealed that both isomers exhibit a plane of symmetry. The titration experiments confirmed the interaction of six metal ions; one 'hard' acid $\mathrm{Fe}^{3+}$, and five 'soft' acids $\mathrm{Fe}^{2+}, \mathrm{Cu}^{2+}, \mathrm{Pb}^{2+}, \mathrm{Hg}^{2+}$ and $\mathrm{Ag}^{+}$. All the remaining metal ions examined $\left(\mathrm{Na}^{+}, \mathrm{Ca}^{2+}, \mathrm{Mg}^{2+}, \mathrm{Co}^{2+}, \mathrm{Ni}^{2+}\right.$, $\mathrm{Mn}^{2+}, \mathrm{Cd}^{2+}, \mathrm{Sn}^{2+}, \mathrm{Zn}^{2+}$, and $\mathrm{Al}^{3+}$ ) showed no appreciable interactions. In addition, no interaction was observed for the tetrabutylammonium ions $\mathrm{Cl}^{-}$and $\mathrm{H}_{2} \mathrm{PO}_{4}{ }^{-}$. The stoichiometry of the complex (host-guest)formed for both isomers was found to be 1:4. Binding constant $\mathrm{K}_{\mathrm{d} 1}$ values for both isomers were found to be very low due to complexation at carboxylate functionality of $\alpha$ and $\beta$-alanine. Binding constant $\left(\mathrm{K}_{\mathrm{d} 2}\right)$ values were appreciably high as compared to $\mathrm{K}_{\mathrm{d} 1}$ values because of the complexation at 

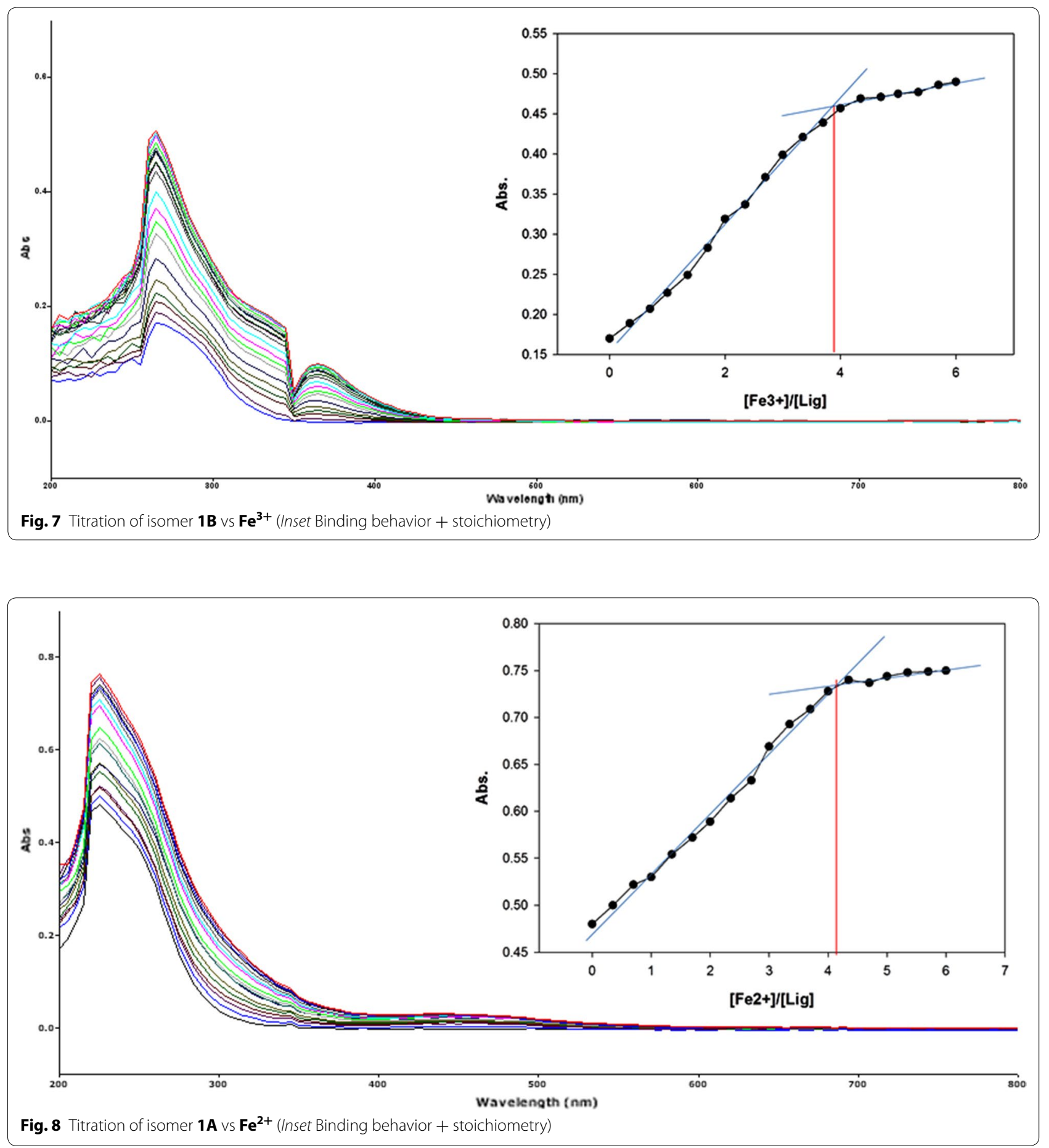

the thiourea functionality of isomers $1 \mathrm{~A}$ and $1 \mathrm{~B}$. On comparing the binding constant $\left(\mathrm{Kd}_{2}\right)$ for both isomers, values for isomer 1A were in the range 4.5-6.8 except for $\left(\mathrm{Pb}^{2+}\right)$ which was 1.2 and for isomer $1 \mathrm{~B}$ binding constant values were found in the range 4.5-9.8 except for $\left(\mathrm{Ag}^{+}\right)$ which was 1.7. The dissociation constant values for both isomers with all metal ions were in relatively close proximity to each other. The next study will be focused on 


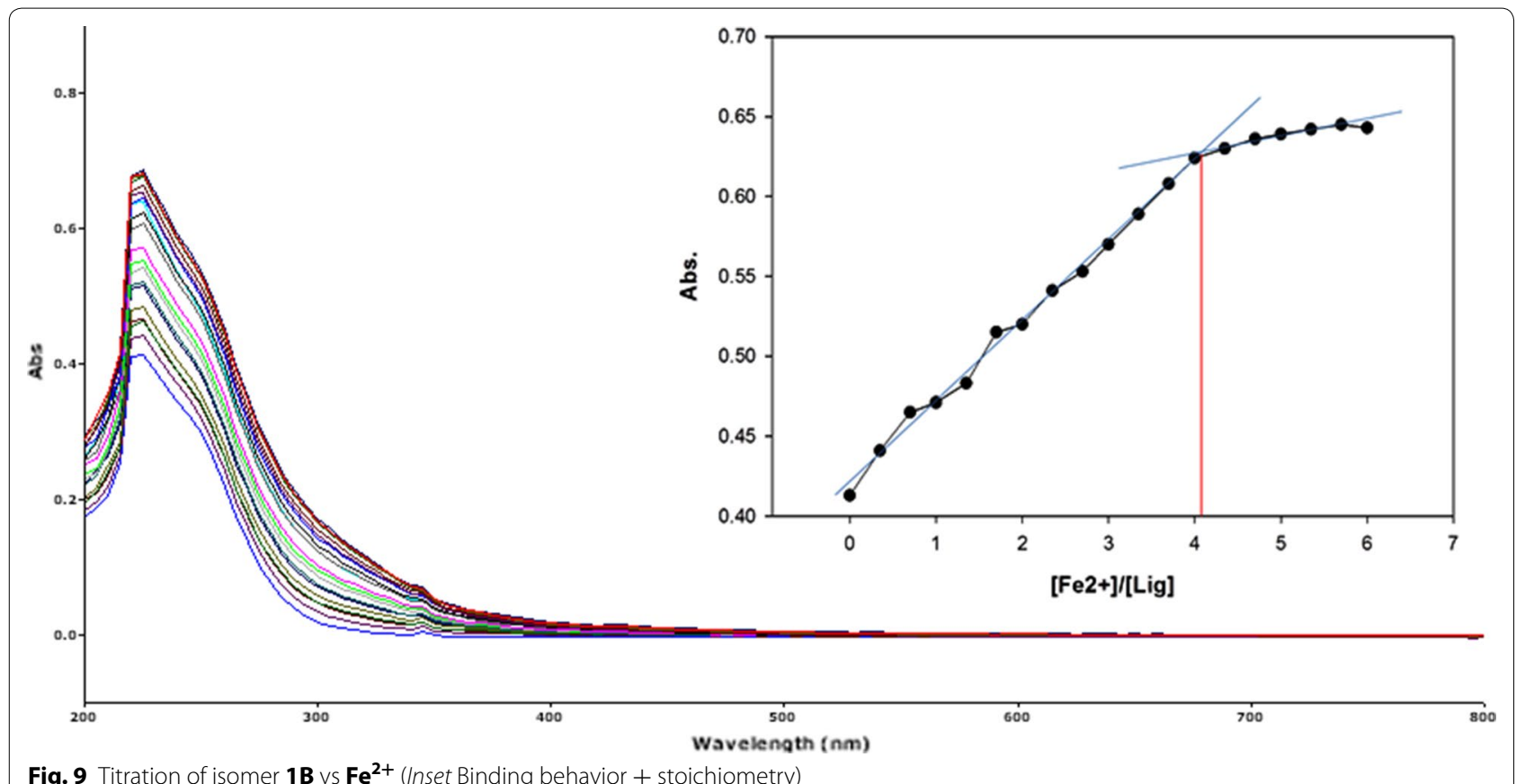

Fig. 9 Titration of isomer $\mathbf{1 B}$ vs $\mathbf{F e}^{\mathbf{2 +}}$ (Inset Binding behavior + stoichiometry)

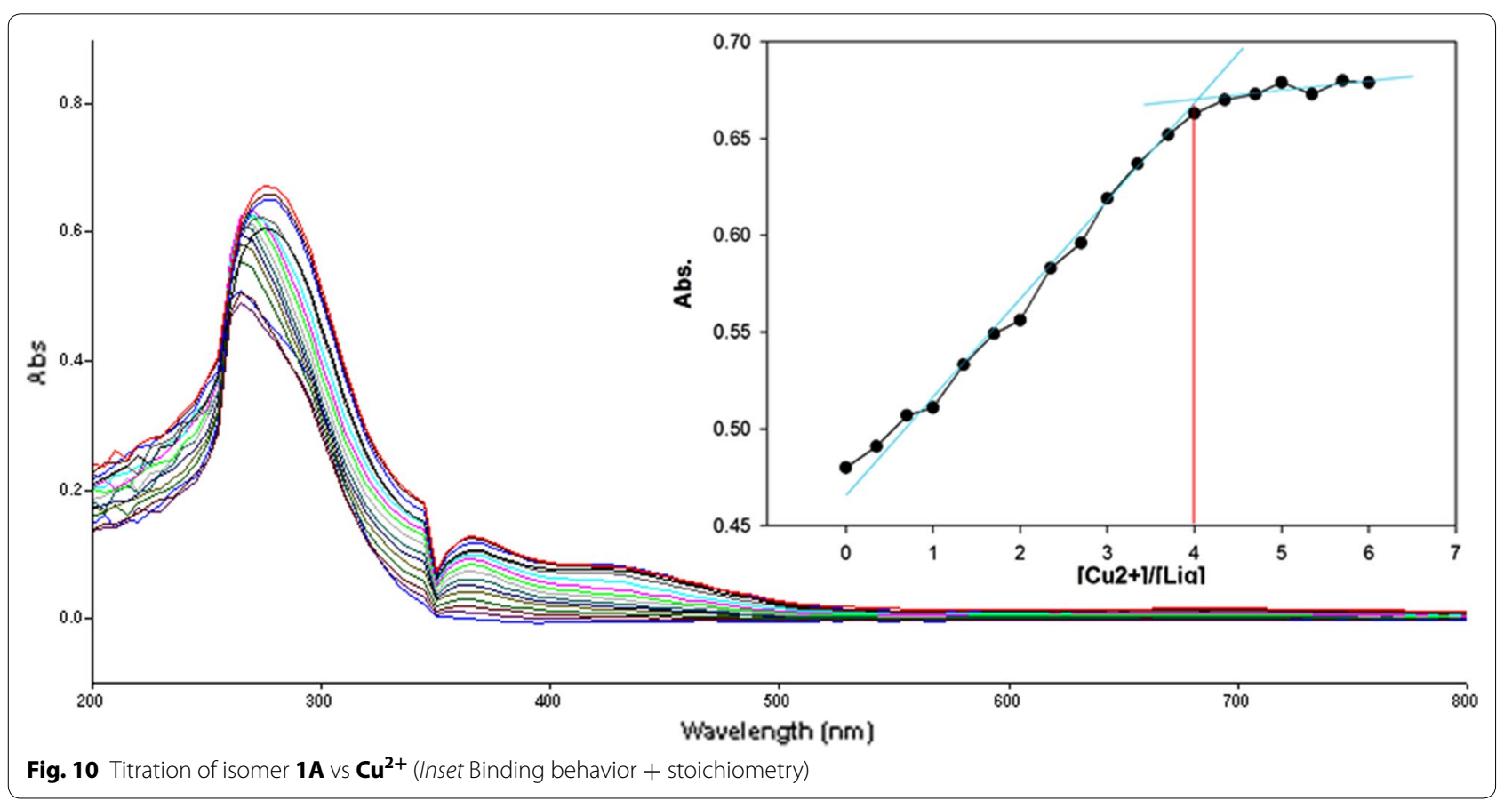

the role of different side chain amino acids/secondary amines towards binding behavior against various metals and based on the data obtained in the present study, the chemical sensor will be fabricated by using newly synthesized compounds for the detection of metal ions. 


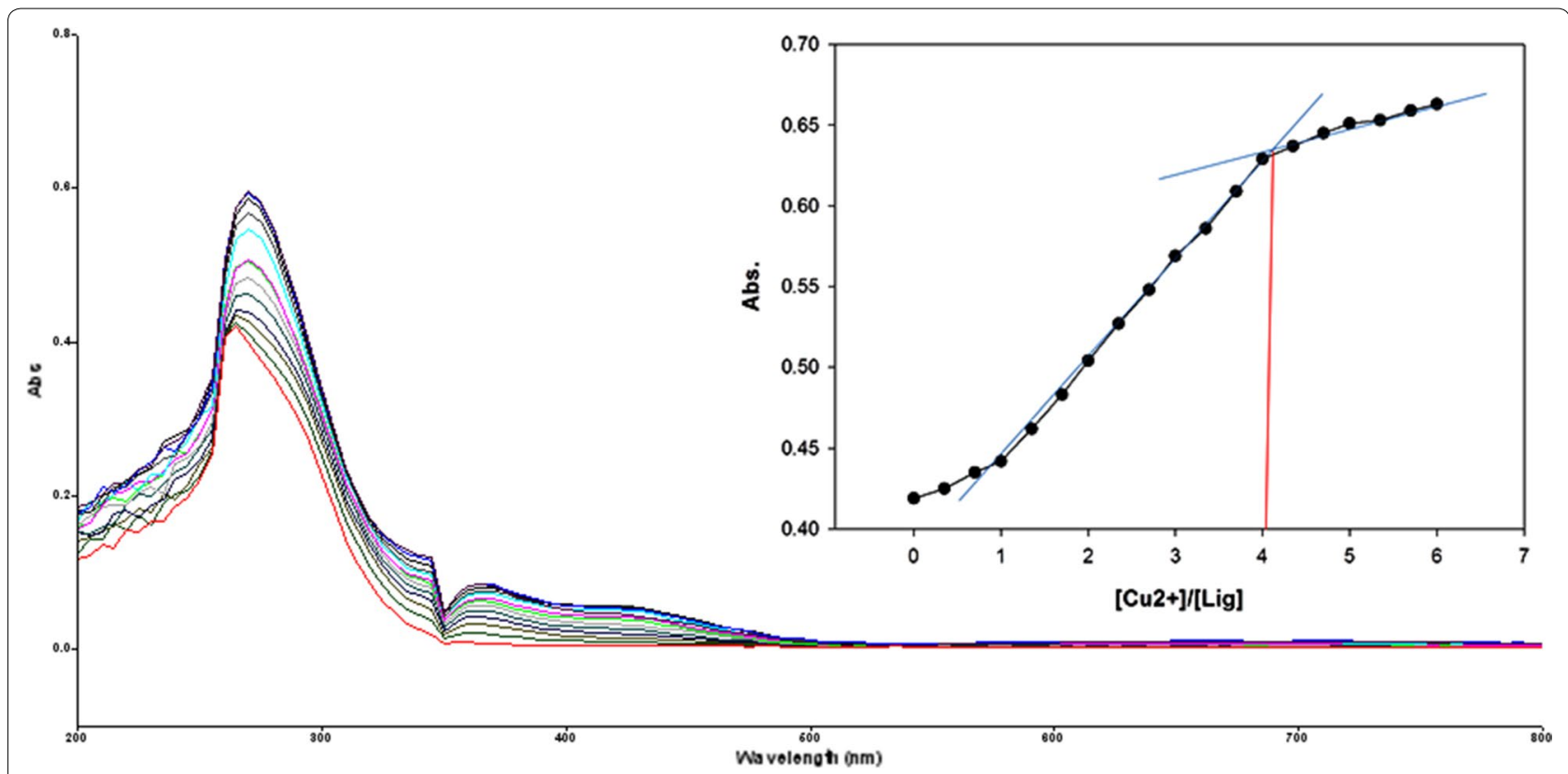

Fig. 11 Titration of isomer $\mathbf{1 B} v \mathrm{~S} \mathbf{C u}^{\mathbf{2 +}}$ (Inset Binding behavior + stoichiometry)

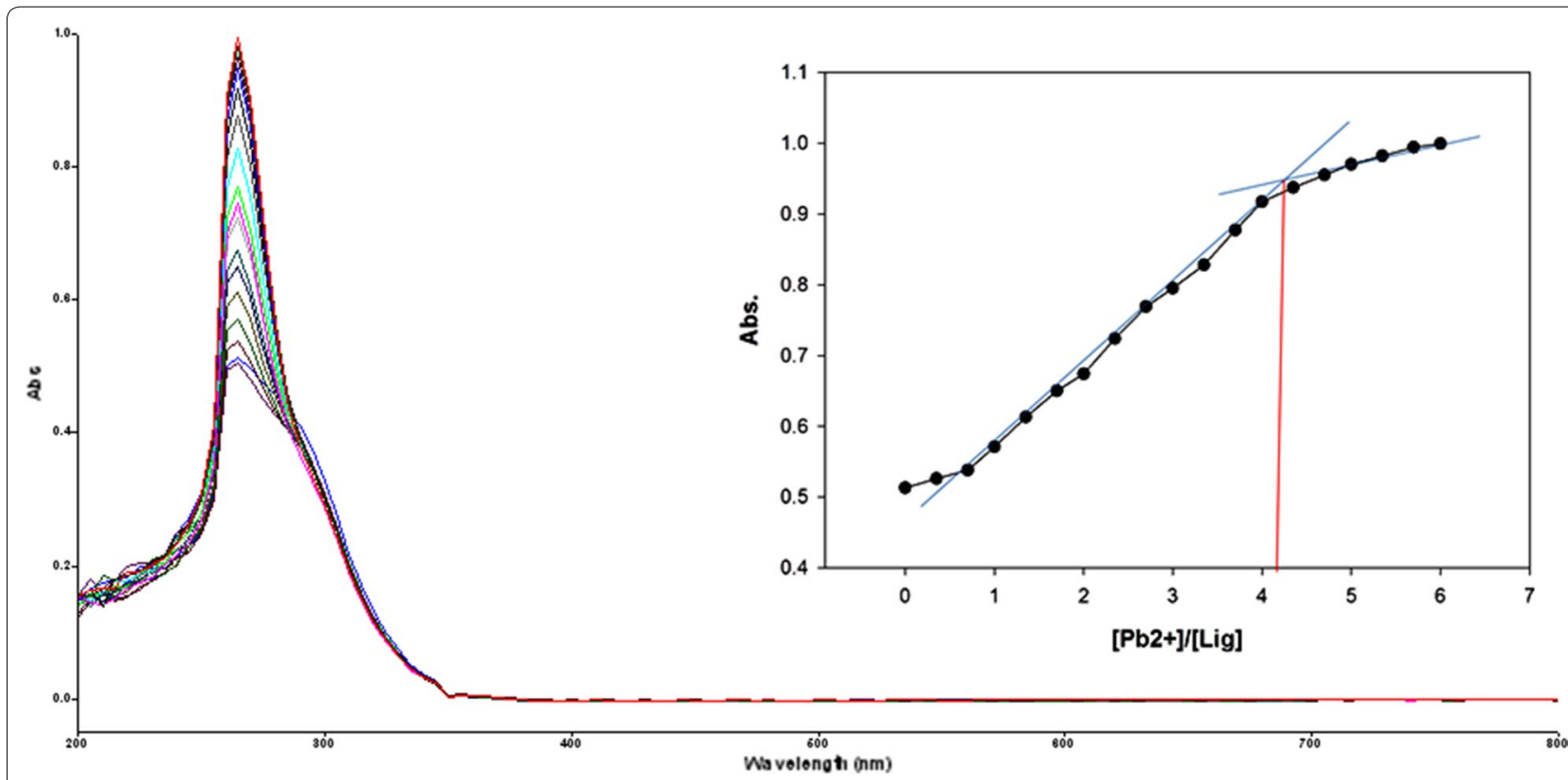

Fig. 12 Titration of isomer $\mathbf{1 A} v \mathbf{\mathbf { P b } ^ { \mathbf { 2 + } }}$ (Inset Binding behavior + stoichiometry) 

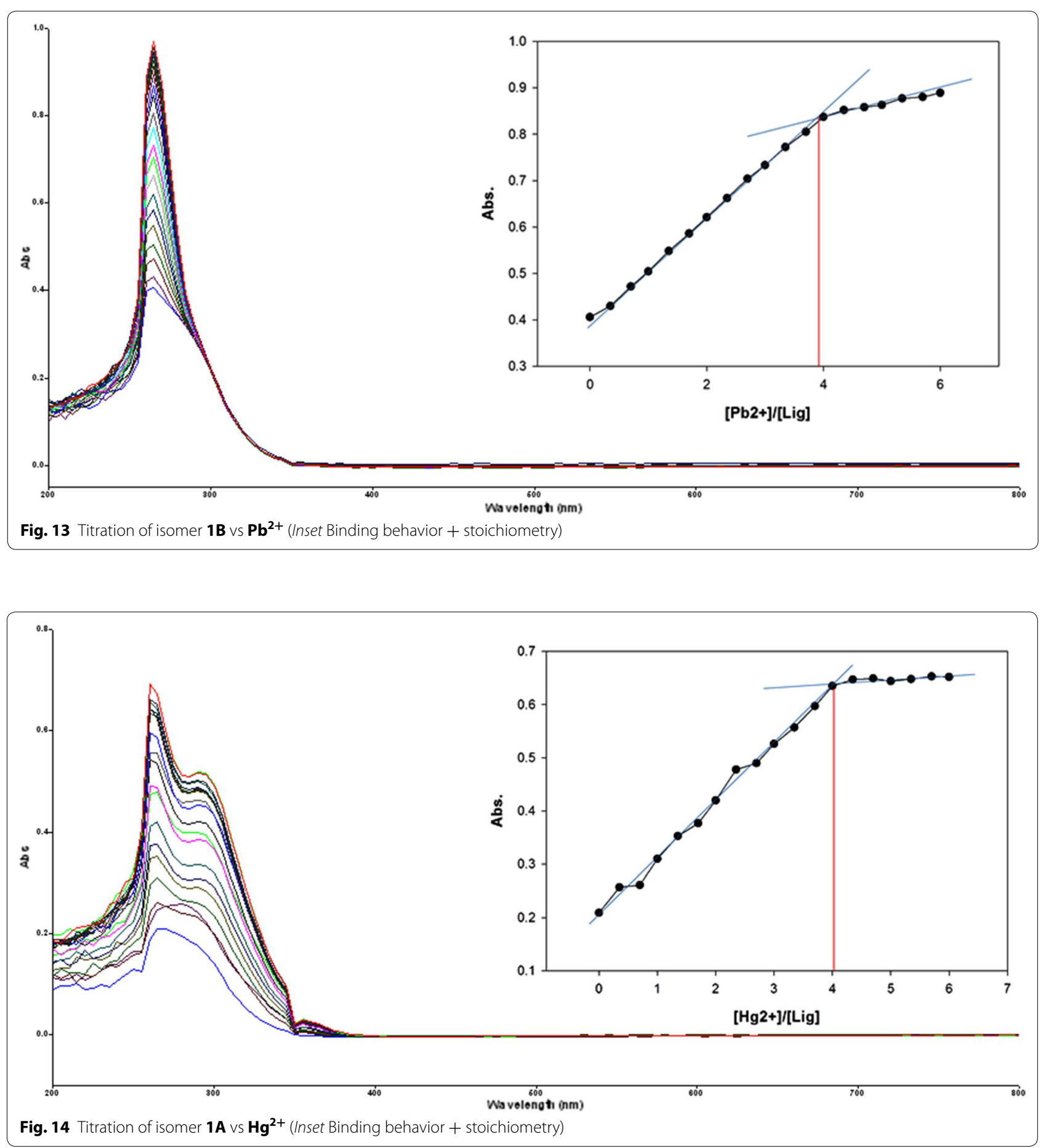


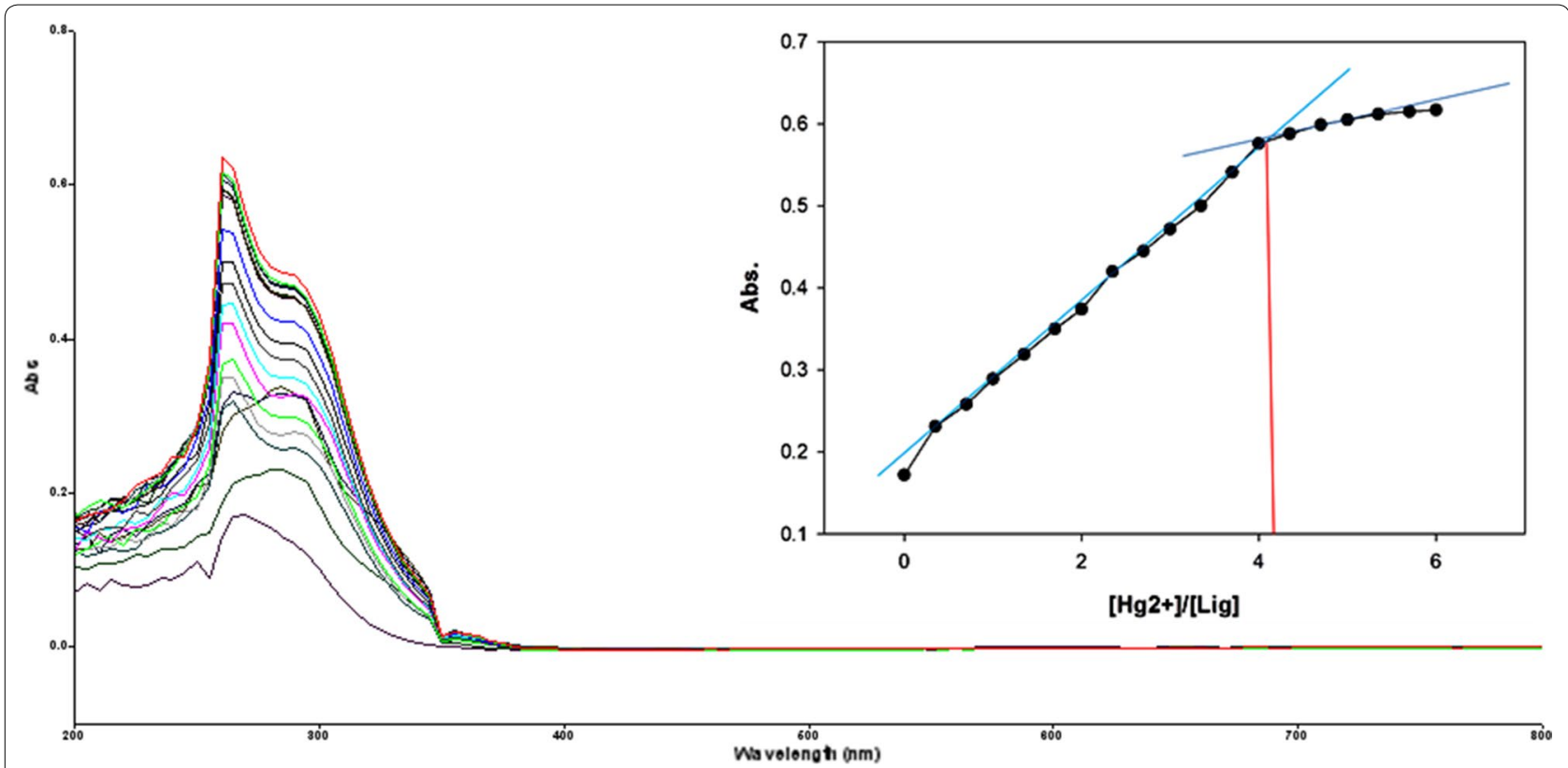

Fig. 15 Titration of isomer $\mathbf{1 B} \vee \mathbf{H g}^{\mathbf{2 +}}$ (Inset Binding behavior + stoichiometry)

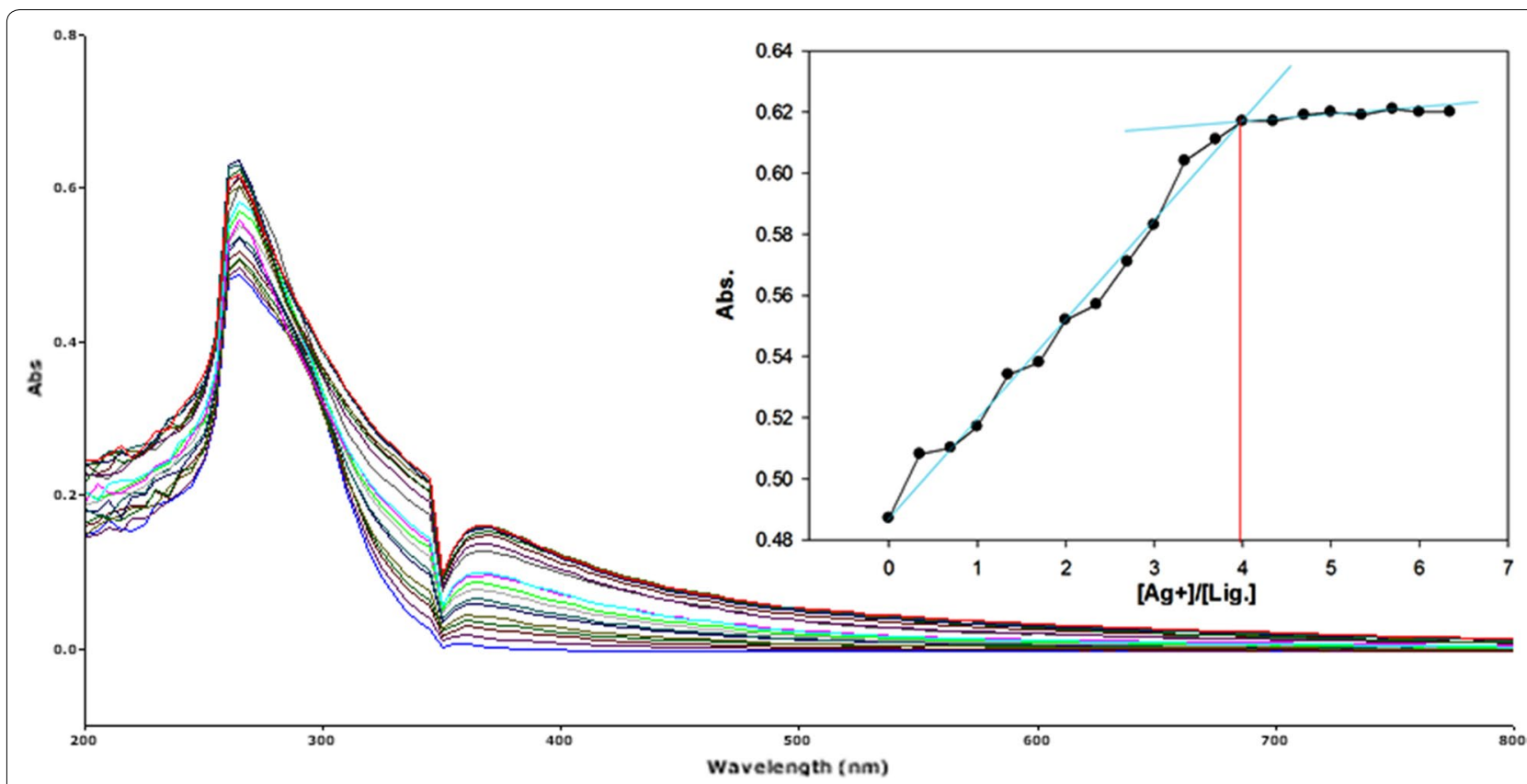

Fig. 16 Titration of isomer $\mathbf{1 A} \vee \mathbf{A} \mathbf{A g}^{+}$(Inset Binding behavior + stoichiometry) 


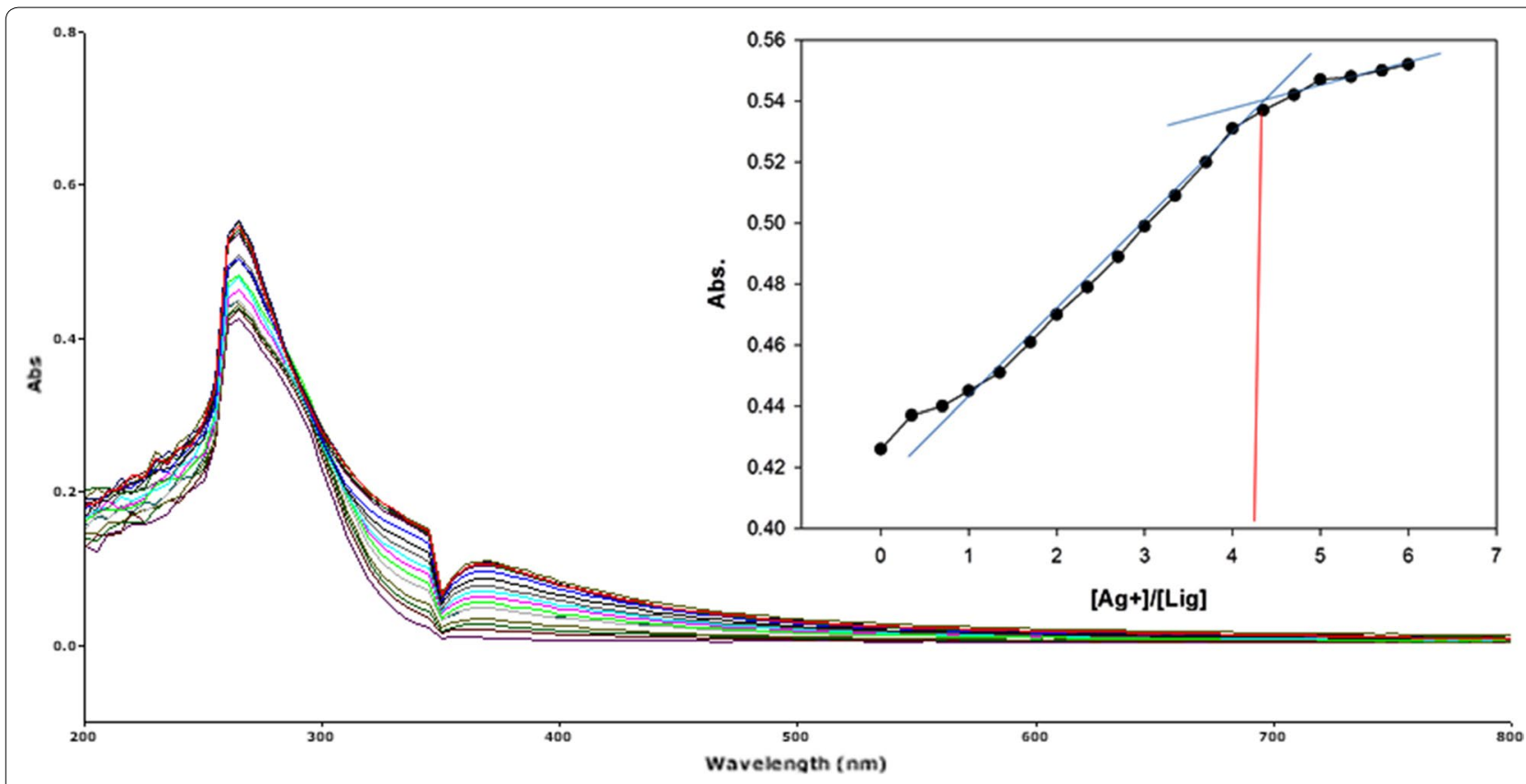

Fig. 17 Titration of isomer 1B $\vee \mathbf{S} \mathbf{A g}^{+}$(Inset Binding behavior + stoichiometry)

\section{Authors' contributions}

IF, BMY and SAH initiated the study. All authors contributed to the synthesis and characterization of new compounds, interpretation of the results and preparation of the manuscript. The experiment and sample analysis were conducted by IF with contributions from BMY and SAH. The binding studies were conducted by IF and SAH with contributions from BMY. All authors read and approved the final manuscript.

\section{Acknowledgements}

The authors wish to thank the School of Chemical Sciences and Food Technology, and the Universiti Kebangsaan Malaysia (DIP-2015-015) for providing necessary facilities. We greatly appreciate the Ministry of Higher Education for providing the funding of the project under Grants PRGS/2/2015/SG01/ UKM/02/1 and FRGS/1/2015/ST01/UKM/02/2 (Project leader Dr. Siti Aishah Hasbullah). Mr. Imran Fakhar would also like to thank Mr. Kamran Fakhar for providing financial assistance, his parents for providing moral support and Mr. Hassanuddin for providing the technical assistance.

\section{Competing interests}

The authors declare that they have no competing interests.

\section{Publisher's Note}

Springer Nature remains neutral with regard to jurisdictional claims in published maps and institutional affiliations.

Received: 24 December 2016 Accepted: 26 July 2017

Published online: 04 August 2017

\section{References}

1. Nencki M (1873) Zur Kenntniss des Sulfoharnstoffs. Ber Dtsch Chem Ges 6:598-600

2. Mitsuo K, Masato S, Keiko T, Tadashi A (2005) A convenient and efficient method for the synthesis of mono- and N,N-disubstituted thioureas. Tetrahedron Lett 46:5841-5843
3. Zullkiplee Wan S H W, Abd Ainaa N, Halim Zainab N, Maya A, Ariff M, Hasnain $\mathrm{H}$ (2014) Bis-thiourea bearing aryl and amino acids side chains and their antibacterial activities. Phosphorus Sulfur Silicon Relat Elem 189:832-838

4. Sun CW, Zhang XD (2007) Synthesis and crystal structure of S-(+)-N'-Tertbutylaminocarbonyl-N-[3-methyl-2-(4-chlorophenyl)butyryl] Thiourea. Chin J Struct Chem 26:153-156

5. Aamer S, Khera Rasheed A, Naeem A, Muhammad L, Imran S, Ulrich F (2010) Synthesis, characterization, crystal structures, and antibacterial activity of some new 1-(3,4,5-trimethoxybenzoyl)-3-aryl thioureas. Turk J Chem 34:335-345

6. Sohail S, Naghmana R, Muhammad A, Rizwan H (2010) Synthesis, characterization and antibacterial activity of nickel (II) and copper (II) complexes of $\mathrm{N}$-(alkyl(aryl)carbamothioyl)-4-nitrobenzamide. Eur J Chem 1:200-205

7. Eweis M, Elkholy SS, Elsabee MZ (2006) Antifungal efficacy of chitosan and its thiourea derivatives upon the growth of some sugar-beet pathogens. Int J Biol Macromol 38:1-8

8. Dharmarajan S, Perumal Y, Murugesan D, Rathinasababathy T (2007) Antimycobacterial activity of novel 1-(5-cyclobutyl-1,3-oxazol-2-yl)-3-(sub) phenyl/pyridylthiourea compounds endowed with high activity toward multidrug-resistant Mycobacterium tuberculosis. J Antimicrob Chemother 59:1194-1196

9. Bedia KK, Sevim RKK-A (2003) In vivo metabolism of $N$-phenyl- $N^{\prime}$-(3,5dimethylpyrazole-4-yl) thiourea in rats. Eur J Drug Metabol Pharmacokinet 28:273-278

10. Soung M-G, Park K-Y, Song J-H, Sung N-D (2008) Herbicidal activity and molecular similarity of 1-(4-chloro-2-fluoro-5-propargyloxyphenyl)-3-thiourea derivatives. Soc Appl Biol Chem 51:219-222

11. Saeed A, Batool M (2007) Synthesis and bioactivity of some new 1-tolyl3-aryl-4-methylimidazole-2-thiones. Med Chem Res 16:143-154

12. Sohail S, Naghmana Muhammad A, Rizwan H, Peter GJ (2010) Synthesis, spectroscopic characterization, crystal structure and pharmacological properties of some novel thiophene-thiourea core derivatives. Eur J Chem 1:221-227

13. Das DK (1984) N-a-(5-bromopyridyl)-N'-benzoyl thiourea (BrPBT) as a new chelating agent for the spectrophotometric determination of rhodium (III). Fresh J Anal Chem 318:612 
14. Shome SC, Mazumdar M, Haldar PK (1980) N-Alpha-pyridyl-N'-benzoyl thiourea as a chelating agent for the determination of iridium. J Indian Chem Soc 57:139-141

15. Ghora Mostafa M, Alsaid MS, Al-Dosary MS, Nissan YM, Attia SM (2016) Design, synthesis and anticancer activity of some novel thioureido-benzenesulfonamides incorporated biologically active moieties. Chem Cent J 10:19. doi:10.1186/s13065-016-0161-4

16. Gün B, Gülten K, Nevzat K, Süheyla Ö, Ulrich F, Hakan A (2013) Synthesis and characterization of novel thiourea derivatives and their nickel and copper complexes. J Chem. doi:10.1155/2013/536562

17. Alkherraz Abdulfattah M, Lusta Zaineb I, Zubi Ahmed E (2014) Synthesis and use of thiourea derivative (1-Phenyl-3-Benzoyl-2-Thiourea) for extraction of cadmium ion. Int J Chem Nucl Metall Mater Eng 8:118-120

18. Walid F, Pavel P (2007) Synthesis and reactions of methyl 2-[3-(2-phenylquinazolin-4-yl)thioureido]alkanoates. ARKIVOC 1:236-243

19. Walid F, Ali Ibrahim A I (2007) Efficient synthesis of 1-substituted-4-phenyl-1, 4-dihydro-5H-tetrazole-5-thione and (1-phenyl-1H-tetrazol-5-yl) thioacetyl derivatives. Heteroat Chem 18:637-643

20. Walid F, El Rayes SM, Ali Al (2007) Convenient synthesis of 1-substituted4-methyl-5-oxo[1,2,4]triazolo[4,3-a]quinazolines. ARKIVOC 16:173-186

21. El Rayes SM, Ali Al, Walid F (2008) A convenient synthesis of new amino acid-coupled benzanilides. ARKIVOC 9:86-95

22. Al-M Najim A, Al-H Nahed, Faili NT, Pannecouque C (2010) Amino acid derivatives. Part 5. Synthesis and anti-HIV activity of new sebacoyl precursor derived thioureido-amino acid and phthalimide derivatives. ARKIVOC 9:185-195

23. Werner Alfred (1893) Beitrag zur konstitution anorganischer verbindungen. Zeitschrift für Anorganische und Allgemeine Chemie 3:267-330

24. Rathod MS, Jadhao SZ (2012) Synthesis and structural investigation of nickel metal-ligand (thiourea derivative) complexes. J Chem Pharm Res 4:1629

25. William H, Brian KN, Rickard CEF (2001) Platinum(II) complexes of chelating and monodentate thiourea monoanions incorporating chiral, fluorescent or chromophoric groups. Inorg Chim Acta 320:101-109

26. Pearson RG (1963) Hard and soft acids and bases. J Am Chem Soc 85:3533

27. Xuefang S, Zhenhua Y, Jiajia F, Peipei Z, Xiufang X (2015) The synthesis and anion recognition property of symmetrical chemosensors involving thiourea groups: theory and experiments. Sensors 15:28166-28176. doi:10.3390/s151128166

28. Khansari ME, Wallace KD, Hossain MA (2014) Synthesis and anion recognition studies of a dipodal thiourea-based sensor for anions. Tetrahedron Lett 55:438-440

29. Zhenyu Z, Shenzhou L, Chunming S, Dongmei X (2015) A single thioureaappended 1,8-naphthalimide chemosensor for three heavy metal ions: $\mathrm{Fe}^{3+}, \mathrm{Pb}^{2+}$, and $\mathrm{Hg}^{2+}$. Sens Actuat B 208:258-266

30. Al-Kady AS, Gaber M, Hussein MM, El-Z Ebeid (2009) Fluorescence enhancement of coumarin thiourea derivatives by $\mathrm{Hg}^{2+}, \mathrm{Ag}^{+}$, and silver nanoparticles. J Phys Chem 113:9474

31. Sheldrick GM (1997) SHELXTL. Version 6.14 program for crystal structure determination. University of Gottingen, Gottingen
32. Hamza MA, Siti Aishah H, Yamin Bohari M (2015) Synthesis, characterization and X-ray structure of N-(4-bromobutanoyl-N"-(2-3- and 4-methylphenyl) thiourea. Chin J Struct Chem 34:379-385

33. Wen Y, Weiqun Z, Zhengjiang Z (2007) Structural and spectroscopic study on N-2-fluorobenzoyl- $N^{\prime}$-4-methoxyphenylthiourea. J Mol Struct 828:46-53

34. Hakan A, Ulrich F, Nevzat K, Gün B (2007) The molecular structure and vibrational spectra of 2-chloro- $\mathrm{N}$-(diethylcarbamothioyl)benzamide by Hartree-Fock and density functional methods. Spectrochim Acta A Mol Biomol Spectrosc 68:1347-1355

35. Sitti R, Bunbun B (2009) Kinetics of the oxidation of vitamin C. Prosiding Seminar Kimia Bersama UKM-ITB VIII:9-11

36. Shankaranrayana ML, Patel CC (1965) Infrared absorption studies on some derivatives of xanthic, dithiocarbamic and trithiocarbonic acids. Spectrochim Acta A Mol Spectrosc 21:93-105

37. Abosadiyaa HM, Anouar EH, Hasbullah SA, Yamin BM (2015) Synthesis, X-ray, NMR, FT-IR, UVNis, DFT and TD-DFT studies of $\mathrm{N}$-(4-chlorobutanoyl)- $\mathrm{N}^{\prime}$-(2-, 3- and 4-methylphenyl)thiourea derivatives. Spectrochim Acta A Mol Spectrosc 144:115-124

38. Freeman RA (1997) Handbook of Nuclear Magnetic Resonance, 2nd edn. Longman, London

39. Frank HA, Olga K, David GW, Lee B, Guy Orpen A, Robin T (1987) Tables of bond lengths determined by $X$-ray and neutron diffraction. Part 1 Bond lengths in organic compounds. J Chem Soc Perkin Trans 2:S1-S19. doi:10.1039/P298700000S1

40. Hamza MA, El Salem A, Bohari MY (2009) synthesis and X-ray structure study of cis-trans 3-(3-biphenyl carbonylthioureido)propanoicacid(i) and n-(4-biphenyl carbonyl)-n'-(3-hydroxyphenyl)thiourea(II). Rasayan J Chem 2:572-576

41. Guangyan Q, Taolei S, Zhihong C, Xi Y, Xiaojun W, Yongbing H (2009) 'Naked-eye' enantioselective chemosensors for $\mathrm{N}$-protected amino acid anions bearing thiourea units. Chirality 21:363-373. doi:10.1002/ chir.20593

42. Abosadiya HA, Yamin BM (2007) Synthesis and molecular structure of the complexes of trimethyl and tributyltin chloride with 3-(3-benzoylthiouredo)propionic acid. J Sains MIPA 13:73-76

43. Zhengqian L, Ying Z, Kai Y, Zhu Y, Yan L, Jun R (2014) A new fluorescence "turn-on" type chemosensor for $\mathrm{Fe}^{3+}$ based on naphthalimide and coumarin. Dyes Pigments 105:711

44. Kalpana RD, Bryan M, Alamgir MA (2010) Rational design of a macrocyclebased chemosensor for anions. Tetrahedron Lett 51:1329-1332

45. Ukpebor EE, Okolo PO (2004) Stoichiometry of quinol/ammonium-nitrogen complex using spectrophotometry. J Chem Soc Pak 26:207-211

46. Kabbani AT, Ramadan H, Hammud HH, Ghannoum AM, Mouneimne Y (2005) Synthesis of some metal complexes of N-[(benzoylamino)thioxomethyl]-aminoacid (HL). J Univ Chem Technol Metall 40:339-344

47. Asuero AG, Sayago A, González AG (2006) The correlation coefficient: an overview. Crit Rev Anal Chem 36:41-59

48. Sauer RT. Review of chemical equilibrium. 1999. https://www.coursehero. com/file/6535314/fa01lec07/. Accessed 11 July 2016

\section{Submit your manuscript to a SpringerOpen ${ }^{\odot}$ journal and benefit from:}

- Convenient online submission

- Rigorous peer review

- Open access: articles freely available online

- High visibility within the field

- Retaining the copyright to your article

Submit your next manuscript at springeropen.com 